\title{
Can a Conservative Rehabilitation Strategy Improve Shoulder Proprioception? A Systematic Review
}

\author{
Amanda L. Ager, Dorien Borms, Magali Bernaert, Vicky Brusselle, Mazarine Claessens, \\ Jean-Sébastien Roy, and Ann Cools
}

\begin{abstract}
Context: Proprioception deficits contribute to persistent and recurring physical disability, particularly with shoulder disorders. Proprioceptive training is thus prescribed in clinical practice. It is unclear whether nonsurgical rehabilitation can optimize shoulder proprioception. Objectives: To summarize the available evidence of conservative rehabilitation (ie, nonsurgical) on proprioception among individuals with shoulder disorders. Evidence Acquisition: PubMed, Web of Science, and EBSCO were systematically searched, from inception until November 24, 2019. Selected articles were systematically assessed, and the methodological quality was established using the Dutch Cochrane Risk of Bias Tool and the Newcastle-Ottawa Quality Assessment Scale. The Preferred Reporting Items for Systematic reviews and Meta-Analyses guidelines were utilized for this review. The conservative treatments were categorized as follows: (1) conventional therapy, (2) proprioceptive training, (3) elastic kinesiology tape, and (4) other passive therapies. Evidence Synthesis: Twelve articles were included, yielding 58 healthy control shoulders and 362 shoulders affected by impingement syndrome, glenohumeral dislocations, nonspecific shoulder pain, rotator cuff dysfunction, or subluxation poststroke. The level of agreement between the evaluators was excellent (84.9\%), and the studies were evaluated to be of fair to excellent quality (risk of bias: $28.5 \%-100 \%$ ). This review suggests, with moderate evidence, that proprioceptive training (upper-body wobble board or flexible foil training) can improve proprioception in the midterm. No decisive evidence exists to suggest that conventional therapy is of added value to enhance shoulder proprioception. Conflicting evidence was found for the improvement of proprioception with the application of elastic kinesiology tape, while moderate evidence suggests that passive modalities, such as microcurrent electrical stimulation and bracing, are not effective for proprioceptive rehabilitation of the shoulder. Conclusions: Proprioceptive training demonstrates the strongest evidence for the effective rehabilitation of individuals with a shoulder proprioceptive deficit. Elastic kinesiology tape does not appear to affect the sense of shoulder proprioception. This review suggests a possible specificity of training effect with shoulder proprioception.
\end{abstract}

Keywords: joint position sense, kinaesthesia, glenohumeral joint, physiotherapy

Proprioception is among the many somatosensory senses (ie, thermoception, nociception, equilibrioception, mechanoreception $)^{1}$ that we rely upon to guide our body and limbs through space. It is the ability to detect body positioning and movement, as well as force and velocity, in the absence of visual feedback. ${ }^{2}$ The nomenclature of proprioception has evolved to reflect an overarching theme, which includes kinesthesia (the awareness of passive or active joint movement), joint position sense (the reproduction of joint angles actively or passively), as well as our sense of force production (force-matching, sense of heaviness, tension, and effort), and changes in limb or joint velocity (sense of velocity).,

Proprioception is a complex entity, with many interacting sensory components. Proprioceptive mechanoreceptors (proprioceptors) within the joint capsule, ligaments, muscles, and peripheral cutaneous tissues feed information to the peripheral nervous system and central nervous system for processing, ${ }^{4}$ ultimately resulting in a feedback motor command and a voluntary movement at a joint. A healthy sensorimotor loop gives us the ability to initiate

Ager, Borms, Bernaert, Brusselle, Claessens, and Cools are with the Department of Rehabilitation Sciences and Physiotherapy, Faculty of Medicine and Health Sciences, Ghent University, Ghent, Belgium. Ager and Roy are also with the Centre Interdisciplinaire de Recherche en Réadaptation et Intégration Sociale (CIRRIS), Quebec City, QC, Canada. Roy is also with the Department of Rehabilitation, Faculty of Medicine, Laval University, QC, Canada. Ager (Amanda.Ager@ UGent.be) is corresponding author. precise movements and maintain a level of homeostasis within our neuromuscular system. Sensorimotor control is the management of movements, balance, posture, and joint stability by our central nervous system. ${ }^{5,6}$ In this vein, due to the high mobility of the glenohumeral joint, a strong sense of sensorimotor control is among the leading defenses of the shoulder for the prevention of injury. We can therefore surmise that an intact sense of proprioception contributes to the active stabilization and healthy movement patterns of the shoulder. ${ }^{3,7}$

Shoulder injuries are known to be associated with pain, a decreased range of motion (ROM), and loss of strength, as well as an impaired sense of proprioception. ${ }^{8-10}$ Indeed, proprioception deficits are well documented among shoulder injuries, including rotator cuff (RC) pathologies, ${ }^{11,12}$ shoulder instability, ${ }^{13,14}$ subacromial impingement syndrome (SIS), ${ }^{15-19}$ and adhesive capsulitis. $^{20,21}$ Moreover, shoulder proprioception deficits have been shown among specific populations, such as overhead athletes. $^{22-26}$ Proprioceptive deficits of the shoulder have also been linked to the presence of pain and injury to localized tissues, such as the joint capsule, ligaments, and the labrum and pericapsular muscles. ${ }^{10,13,15}$ It is therefore understandable that proprioceptive deficits are affiliated with recurring physical limitations and disability. ${ }^{10,27,28}$

Even though there is a relationship between shoulder pathologies, functional limitations, ${ }^{10}$ and a decreased sense of proprioception, there is a lack of research suggesting specific rehabilitation 
strategies for the optimization of shoulder proprioception. At present, the treatments of shoulder musculoskeletal disorders are often surgical or conservative in nature. Conservative treatments for the shoulder include conventional rehabilitative therapy, such as ROM and stretching, ${ }^{29}$ passive modalities, ${ }^{30,31}$ manual therapy, ${ }^{32-34}$ various forms of taping, ${ }^{19,25}$ and exercise prescription, ${ }^{35,36}$ including strengthening, motor control, and proprioceptive training. ${ }^{17,37-40}$

To our knowledge, there has yet to be a comprehensive literature review exploring the effects of conservative rehabilitation on the sense of shoulder proprioception. Therefore, the purpose of this systematic review was to summarize the available evidence within the literature concerning conservative rehabilitation strategies for improving proprioception in patients with musculoskeletal disorders of the shoulder complex.

\section{Method}

\section{Literature Search Strategy}

The literature was systematically searched from inception until November 24, 2019, by 4 evaluators (M.B., V.B., M.C., and A.L.A.) by using the medical databases PubMed, Web of Science, and EBSCO, as well as by performing a manual search of references from all retrieved articles. Specific key words, such as shoulder, proprioception, rehabilitation, exercise, and treatment, were utilized (Table 1). Medical Subject Headings terms, as well as truncations and wildcards, were also used and adapted for each database.

\section{Study Selection}

The screening of the title and abstract of each article was performed by 2 independent reviewers (M.B. and/or M.C. and/or V.B.). Subsequently, the full texts of the remaining articles were revised for inclusion and a consensus on eligibility. If a consensus could not be reached, a third evaluator (A.L.A. or D.B.) was consulted until a unanimous decision was reached. Articles were included if (1) the study population included a shoulder pathology or pain;
(2) at least one proprioceptive measurement was used to define an outcome of intervention; (3) a conservative, nonsurgical, and rehabilitation approach was used for the shoulder complex; (4) the outcome measurements were taken during or following an intervention or rehabilitation program; (5) the article was written in English, Dutch, or French; and (6) the article published from the year 2000 to present up-to-date evidence (Table 2).

\section{Methodological Quality Assessment}

The quality and risk of bias of each study was assessed by 2 blinded reviewers (M.B. and/or V.B. and/or M.C.), which again included a third reviewer (A.L.A. or D.B.) if a consensus could not be reached. Included randomized controlled trials (RCTs), ${ }^{16-19,25,41,42}$ were evaluated using the Dutch Cochrane Risk of Bias Tool for RCTs $^{43,44}$ (Table 3). Case-control studies ${ }^{12,14,26,45,46}$ were assessed by combining elements from the Newcastle-Ottawa Quality Assessment Scale ${ }^{47}$ and the Dutch Cochrane Risk of Bias Tool for casecontrol studies, ${ }^{43,44}$ to ensure an extensive risk of bias assessment. Case-control studies were evaluated on 7 items, as follows: 1 (experimental group), 2 (control group), 3 and 4 (selection criteria), 5 (blinding), 6 (confounding variables), and 7 (classification ruling) (Table 4). To be consistent with scoring, the reviewers clarified the meaning of each item of the tools in advance. The level of evidence of each study was determined by the evidence-based Richtlijn Ontwikkeling method (Table 5a), developed by the Dutch Cochrane Centre and the Dutch Institute for Healthcare Improvement. The classification system ranges from the highest awarded level (A1), which includes systematic reviews and meta-analyses, to the lowest awarded level (D), reflecting expert opinion. The strength of the conclusions was also established using the evidence-based Richtlijn Ontwikkeling system (Table 5b). ${ }^{48-50}$

\section{Interventions}

For the purpose of this review, the terminology used to describe the outlined interventions is presented as they were within the included studies. Following these descriptions, the studies were then

\section{Table 1 Key Terms and MeSH Strategy Employed During the Literature Review}

\begin{tabular}{ll}
\hline PICO process & Keywords/MeSH \\
\hline (P) Population & Shoulder pain [MeSH] OR Shoulder injuries [MeSH] OR shoulder pain* OR shoulder injur* \\
& Free word search (in combination): Instability/Dislocation/Subluxation/Luxation/Pain/Injury/Arthroplasty/Replacement/ \\
& Impingement/Fracture/Rotator cuff/labr*/Post-operat*/Adhesive capsulitis/Scapular dyskines* \\
& AND \\
& Rehabilitation [MeSH] Physical Therapy Modalities [MeSH] OR Physiotherap* OR Physical therap* OR Proprioception [MeSH] \\
& Free word search (in combination): Motor control/sensorimotor control/Stabili*/Exercise therapy/Training/Rehabilitation/ \\
& Intervention Program/Therapy/Exercise/Treatment \\
& AND \\
& Healthy volunteers [MeSH] OR controls OR shoulder OR pain-free shoulder OR painless shoulder OR healthy OR normal OR \\
& asymptomatic \\
& N.B. Articles included with and without controls. \\
& AND \\
& Proprioception [MeSH] OR Kinesthesis [MeSH] \\
& Free word search (in combination): Joint position sense/Active joint position sense/Passive joint position sense/proprio*/kinest* \\
& OR kinaest* \\
(O) Outcome & Sense of: - movement/joint/velocity/force/effort
\end{tabular}

Abbreviation: MeSH, Medical Subject Headings; N.B. nota bene. 
Table 2 Inclusion and Exclusion Criteria

\begin{tabular}{|c|c|c|}
\hline Selection criteria & Inclusion criteria & Exclusion criteria \\
\hline Population & $\begin{array}{l}\text { Human } \\
\text { Adults }(\geq 19 \text { y) } \\
\text { Adolescents }(13-18 \text { y) } \\
\text { Musculoskeletal disorders of the shoulder }\end{array}$ & $\begin{array}{l}\text { Children }(<13 \text { y) } \\
\text { Animals } \\
\text { Other joints besides the shoulder joint (elbow, wrist, lower limb, and } \\
\text { spine) } \\
\text { Heritable diseases } \\
\text { Neurological conditions (cerebral lesions, spinal cord injuries, nerve, } \\
\text { or plexus injuries) } \\
\text { Connective tissue disorders (Ehlers-Danlos syndrome and Marfan } \\
\text { syndrome) } \\
\text { Systematic disorders (diabetes, lupus, fibromyalgia, rheumatoid } \\
\text { arthritis, and chronic fatigue syndrome) } \\
\text { Healthy population }\end{array}$ \\
\hline Intervention & $\begin{array}{l}\text { Physiotherapy/conservative rehabilitation } \\
\text { Electromyography feedback } \\
\text { Proprioceptive intervention } \\
\text { Kinesio Tape }\end{array}$ & $\begin{array}{l}\text { Infiltrations } \\
\text { Surgical interventions }\end{array}$ \\
\hline Outcome & $\begin{array}{l}\text { During/immediately after an intervention } \\
\text { At least one proprioceptive measurement used to define } \\
\text { outcome of intervention }\end{array}$ & No proprioceptive measurement used to define outcome of intervention \\
\hline Design & $\begin{array}{l}\text { Randomized controlled trial } \\
\text { Nonrandomized controlled trial } \\
\text { Case-control study } \\
\text { Cohort study } \\
\text { Case reports }\end{array}$ & $\begin{array}{l}\text { Systematic review } \\
\text { Meta-analysis } \\
\text { Comment } \\
\text { Review } \\
\text { Ideas and opinions }\end{array}$ \\
\hline Language & $\begin{array}{l}\text { English } \\
\text { French } \\
\text { Dutch }\end{array}$ & All other languages \\
\hline Publication & $\geq$ the year 2000 & $<$ the year 2000 \\
\hline
\end{tabular}

Table 3 Methodological Quality Control for Randomized Controlled Trials

\begin{tabular}{|c|c|c|c|c|c|c|c|c|c|c|c|c|c|c|}
\hline Included Studies & 1 & 2 & $3 a$ & $3 b$ & 4 & 5 & 6 & $7 a$ & $7 b$ & 8 & 9 & 10 & TS & LOE \\
\hline Atya $^{16}$ & + & $?$ & - & $?$ & $?$ & + & + & $?$ & + & + & + & + & $7 / 12$ & $\mathrm{~B}$ \\
\hline Başkurt et al ${ }^{17}$ & + & $?$ & - & $?$ & $?$ & + & + & $?$ & + & + & + & + & $7 / 12$ & B \\
\hline Dilek et $\mathrm{al}^{18}$ & + & + & $?$ & - & + & + & + & $?$ & + & + & + & + & $9 / 12$ & $\mathrm{~B}$ \\
\hline Keenan et $\mathrm{al}^{19}$ & + & $?$ & + & - & $?$ & + & + & $?$ & + & $?$ & + & + & $7 / 12$ & B \\
\hline Mörl et $\mathrm{al}^{41}$ & + & $?$ & $?$ & $?$ & $?$ & - & $?$ & $?$ & + & + & - & + & $4 / 12$ & $\mathrm{~B}$ \\
\hline Shih et $\mathrm{al}^{25}$ & + & $?$ & + & - & - & + & + & $?$ & + & + & + & + & $8 / 12$ & B \\
\hline Jung and Choi ${ }^{42}$ & + & $?$ & - & + & $?$ & + & + & $?$ & + & + & + & + & $8 / 12$ & B \\
\hline
\end{tabular}

Abbreviations: LOE, level of evidence; TS, total score; -, score not fulfilled; ?, answer unclear; +, score fulfilled.

$1=$ The allocation of the intervention to the patients was randomized.

$2=$ A nonindependent researcher was responsible for selection and consent process, but was not involved in the randomization process.

$3 \mathrm{a}=$ Patients were blind for intervention.

$3 \mathrm{~b}=$ The researchers who provided treatment were blind for intervention.

$4=$ The assessors of the effect of intervention were blind for intervention

$5=$ Both groups were comparable at baseline. (If negative: a correction was made in the analysis.)

$6=$ A follow-up measurement of an adequate proportion of the included population was executed. (If negative: there was no selective.)

$7 \mathrm{a}=$ The researcher who analyzes the data of the 2 groups was blind for intervention.

$7 \mathrm{~b}=$ The patients were analyzed in the group in which they were randomized.

$8=$ The groups were treated equally, apart from intervention.

$9=$ Selective publication of results is excluded.

$10=$ There was no conflict of interest for publication.

categorized based on similar types of interventions, which includes the following 4 clusters: (1) conventional therapy (movement training, manual therapy, stretching, strengthening, scapular stability exercise, and patient education); (2) proprioceptive training (flexible foil, wobble board training, and proprioceptive training); (3) elastic kinesiology tape (Kinesiology Tape, SKT-X-050; Nitoms, Inc, Tokyo, Japan); and (4) other passive therapies (microcurrent electrical stimulation [MENS], transcutaneous electrical nerve stimulation 
Table 4 Methodological Quality Control for Case-Control Studies

\begin{tabular}{|c|c|c|c|c|c|c|c|c|c|}
\hline Included Studies & 1 & 2 & 3 & 4 & 5 & 6 & 7 & TS & LOE \\
\hline Chu et $\mathrm{al}^{45}$ & + & + & $?$ & $?$ & - & + & - & $3 / 7$ & $\mathrm{~B}$ \\
\hline Naughton et $\mathrm{al}^{14}$ & + & + & - & - & $?$ & - & - & $2 / 7$ & $\mathrm{~B}$ \\
\hline Salles et $\mathrm{al}^{26}$ & + & + & + & + & $?$ & + & + & $6 / 7$ & $\mathrm{~B}$ \\
\hline Pairot de Fontenay et $\mathrm{al}^{46}$ & + & + & + & + & + & + & + & $7 / 7$ & $\mathrm{~B}$ \\
\hline de Oliveira et al $^{12}$ & + & + & + & + & - & + & + & $6 / 7$ & B \\
\hline
\end{tabular}

Abbreviations: LOE, level of evidence; NOS, Newcastle-Ottawa Quality Assessment Scale; TS, total score; -, score not fulfilled; ?, answer unclear; +, score fulfilled. Note: Combination of NOS and the Dutch Cochrane Risk of Bias Tool for case-control studies.

$1=$ The patient group is defined adequately (NOS and Dutch Cochrane).

$2=$ The control group is defined adequately (NOS and Dutch Cochrane).

$3=$ The selection of the patients is valid (Dutch Cochrane).

$4=$ The selection of controls is valid (Dutch Cochrane).

$5=$ The assessors of the effect of exposure were blind for exposure (Dutch Cochrane).

$6=$ A correction was made for confounding variables in the analysis (Dutch Cochrane).

(+) Agreed-upon grading by the evaluators

Vision: blindfolded

Cutaneous sensation eliminated (exposure of tested area)

Auditory (if necessary): noise-canceling headphones

Randomization of angles

$7=$ Misclassification can be ruled out (Dutch Cochrane).

(+) Agreed-upon grading by the evaluators

Clinical diagnosed (tests, subjective by questionnaires) AND

Medical imaging techniques used AND

Diagnostic criteria

(-) Agreed upon grading by the evaluators

Only clinical diagnosed OR

Not meeting diagnostic criteria OR

No objective medical imaging techniques used

\section{Table 5 (a) and (b) The Evidence-Based Guidelines Developed by the Dutch Cochrane Centre and the Dutch Institute for Healthcare Improvement (CBO) for the Determination of Level of Evidence and Strength of Conclusion of Scientific Studies ${ }^{48-50}$}
(a) $\mathrm{CBO} / \mathrm{EBRO}$ classification
for level of evidence

$\mathrm{A} 1^{\mathrm{a}}$
$\mathrm{A} 2$
$\mathrm{~B}$
$\mathrm{C}$
$\mathrm{D}$
Noncomparative studies
$\mathrm{D}$
Expert opinion
(b) $\mathrm{CBO} / \mathrm{EBRO}$ strength
of conclusion
1
2
$1 \mathrm{~A} 1$ or at least 2 independent A2 studies
1 A 2 or at least 2 independent B studies
$1 \mathrm{~B}$ or $\mathrm{C}$ study or conflicting evidence
3
4
Expert opinion

Systematic reviews and meta-analyses, based on minimally 2 independent A2 studies

RCTs: double-blinded, with sound methodology and sufficient sample size

Comparative studies, but lacking the quality criteria of A2 (including cohort studies and case-control studies)

Abbreviations: CBO, the Dutch Cochrane Centre and the Dutch Institute for Healthcare Improvement; EBRO, evidence-based Richtlijn Ontwikkeling; RCT, randomized control trial.

${ }^{a}$ An A1 level of evidence was not awarded in our review, as we did not include systematic reviews or meta-analyses for evaluation.

[TENS], hot packs, nonelastic tape, or bracing). Although KT, also referred to as proprioceptive tape, is considered to be a passive modality, it is an intervention that has been hypothesized to affect shoulder proprioception. ${ }^{19,51-53}$ For this reason, it was categorized independently from the other passive modalities to evaluate its effect on shoulder proprioception. With respect to proprioceptive training, the following definition suggested by Aman et $\mathrm{al}^{54}$ will be adhered to throughout our review: "Proprioceptive training is an intervention that targets the improvement of proprioceptive function. It focuses on the use of somatosensory signals such as proprioceptive or tactile afferents."

\section{Data Extraction}

Information was systematically extracted from each study by 2 blinded reviewers (M.B. and/or M.C. and/or V.B.), which included the following: study design, population, baseline measurement, 
applied interventions, follow-up, and outcome measurements and the main results of each study.

\section{Results}

\section{Study Selection and Evaluator Level of Agreement}

A total of 1130 articles were identified. Two hundred and eightyone duplicates were removed, resulting in 849 articles. Further screening of the titles, abstracts, and the full articles resulted in 12 studies that met the eligibility criteria and were, subsequently, included in this systematic review (Figure 1). Of the 12 included studies, 7 were RCTs ${ }^{16-19,25,41,42}$ and 5 were case-control studies. ${ }^{12,14,26,45,46}$ The systematically extracted data of each article are presented in Appendix.

During the consensus meeting, there was an $84.9 \%$ level of agreement between the 3 independent reviewers in the overall quality scores. The methodological quality scores (Tables 3 and 4) were widely dispersed regarding the RCT studies (mean: 60\%, range: $33 \%-75 \%$ ) and the case-control studies (mean: 68\%, range: $28 \%-100 \%)$.

\section{Population}

A total of 405 participants and 420 shoulders were evaluated (pathological: 362 and healthy: 58), where 15 participants acted as their own controls with the contralateral shoulder. ${ }^{14}$ The evaluation of healthy shoulders included the contralateral shoulder or from a healthy control group. The patient population consisted of individuals affected by SIS ( $\mathrm{n}=161$ participants), ${ }^{16-19}$ as well as, specifically, overhead athletes with SIS ( $\mathrm{n}=30),{ }^{25}$ unstable shoulders with previous glenohumeral anterior dislocations $(\mathrm{n}=$ 50 participants), ${ }^{14,45}$ nonspecific shoulder pain $(n=22$ participants), ${ }^{41} \mathrm{RC}$ dysfunctions ( $\mathrm{n}=62$ participants), ${ }^{12,46}$ and a shoulder subluxation following a stroke $(\mathrm{n}=36$ participants $) .{ }^{42}$ The average
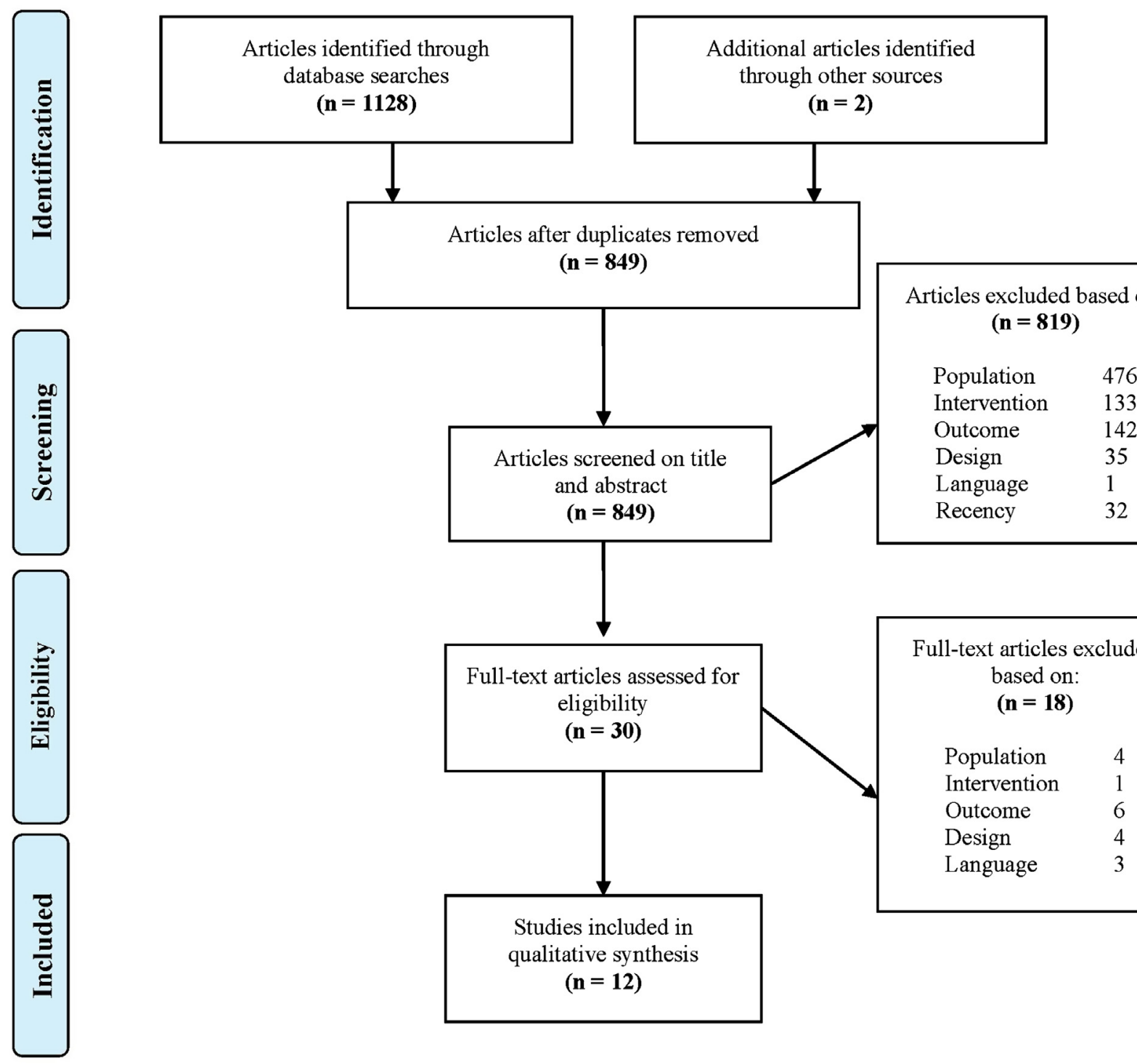

Figure 1 - Literature selection process performed according to the Preferred Reporting Items for Systematic Reviews and Meta-Analyses statement. 
mean age (SD) ranged from 21 (3.7) to $58(2.0)$ years, and the majority of the participants were male (55.7\%).

\section{Interventions}

All included studies investigated the effects of a shoulder rehabilitation intervention on a sense of shoulder proprioception, including active joint position sense (AJPS), passive joint position sense (PJPS), and kinesthesia. No studies were identified regarding the sense of velocity or sense of force. Eleven studies ${ }^{12,16-19,25,26,41,42,45,46}$ investigated the effects of the intervention on the pathological shoulder only, whereas Naughton et al ${ }^{14}$ trained and assessed both shoulders ( 1 healthy and 1 affected by an anterior dislocation). The duration of the training periods varied between a single session ${ }^{12,19,25,45}$ and 4 to 12 weeks of therapy. ${ }^{14,16-18,26,41,42,46}$ No studies were identified within the literature that measured the effects of their interventions beyond 12 weeks. The parameters and the specific exercises of the applied interventions can be found in Table 6 .

Conventional Therapy. Six studies applied conventional therapy, which included active rest, ${ }^{18}$ shoulder ROM exercises, ${ }^{17,18,41}$ movement training, ${ }^{46}$ stretching and flexibility training, ${ }^{17,18,46}$ scapular stabilization exercises, ${ }^{17,18}$ strengthening, ${ }^{17,18,26,41,42,46}$ return to function activities, ${ }^{18}$ and patient education. ${ }^{46}$

Proprioceptive Training. Proprioceptive training was classified within this cluster, as per the self-defined "proprioceptive exercises" of each study, while also respecting the definition outlined by Aman et al. ${ }^{54}$ Başkurt et al ${ }^{17}$ employed scapular proprioceptive neuromuscular facilitation techniques to one of their intervention groups. Dilek et al ${ }^{18}$ used exercises such as static weight bearing, upper-extremity balancing exercises, balance boards, and dynamic scapular stabilization exercises with a ball as their proprioceptive training. Furthermore, Mörl et $\mathrm{al}^{41}$ compared 2 training programs: flexible foil versus flexible band (TheraBand, Akron, $\mathrm{OH}$ ) training. Naughton et al ${ }^{14}$ implemented an upper-extremity wobble board program in a weight-bearing position, using a Swiss ball.

Kinesiology Tape. Two studies compared the application of KT to a sham or placebo taping, ${ }^{19,25}$ whereas one study compared the taped shoulder to the nontaped contralateral shoulder. ${ }^{12}$ Shih et a ${ }^{25}$ applied KT to the upper (I-shaped tape) and lower (Y-shaped tape) trapezius muscles and used a 3M Micropore tape (3M, St Paul, MN) without any stretch tension as their placebo. Contrastingly, Keenan et al ${ }^{19}$ also used KT, but applied the tape directly to the evaluated shoulder area, using a 2 "Y" strips and an "I" strip over the supraspinatus and deltoid muscles. They utilized Cover-Roll ${ }^{\circledR}$ tape (BSN Medical Inc, Charlotte, NC) as their placebo taping. de Oliveira et $\mathrm{al}^{12}$ used Tex Classic $^{\circledR}$ KT (Alburquerque, NM), following the application instructions provided by the taping manufacturer (Table 6).

Other Passive Therapies. Three studies evaluated the effects of passive modalities, such as TENS, ${ }^{18}$ a hot pack, ${ }^{18}$ a MENS machine, ${ }^{16}$ or the application of a neoprene sully shoulder stabilizer brace (The Saunders Group Inc, Chaska, MN). ${ }^{45}$

\section{Outcomes}

The included articles examined the shoulder proprioception outcome measures, which included kinesthesia as threshold to detection of passive movement, ${ }^{14,18,19,26}$ PJPS, ${ }^{16-18}$ and AJPS. 12,18,25,26,41,42,45,46 All included studies calculated the mean error between the original target angle and the reproduced angle, as their proprioceptive error (see Appendix).

\section{Follow-Up From Baseline}

Outcome measurements were executed immediately after the intervention, ${ }^{14,16-18}$ after an external intervention (tape or bracing) was applied, ${ }^{12,19,25}$ or following a training program of $4,{ }^{42} 6,{ }^{18,46}$ $8,{ }^{26}$ or 12 weeks $^{41}$ in duration. None of the included studies evaluated the long-term effects surpassing 12 weeks in duration.

\section{Synthesis of Results}

Only 2 included studies reported the effect size of their studied interventions (Table 7). ${ }^{26,46}$

Conventional Therapy. Six studies ${ }^{17,18,26,41,42,46}$ examined the effects of conventional interventions on proprioception. Başkurt et $\mathrm{al}^{17}$ added scapular stabilization exercises to conventional flexibility and strengthening, and demonstrated that the scapular stabilization group experienced a greater improvement in PJPS than the conventional therapy group $(P<.001)$, although both groups improved significantly $(P<.05)$. Second, Dilek et $a^{18}$ found no significant difference in the proprioceptive outcomes between the control group (conventional therapy - hot packs, TENS, and an exercise strengthening program) and the proprioceptive program group (Table 6) immediately or 6 weeks postintervention $(P>.05)$. Both groups improved significantly regarding the kinesthetic sense at $0^{\circ}$ external rotation $(\mathrm{ER} ; P<.05) 6$ weeks postintervention, with an additional improvement in the proprioceptive program group for kinesthetic sense, AJPS, and PJPS at $10^{\circ}$ ER $(P<.05)$ and in the conventional therapy group for AJPS at $0^{\circ} \mathrm{ER}(P<.05)$. Mörl et a $1^{41}$ found no statistically significant differences $(P>.05)$ between the flexible foil training group versus the flexible band (TheraBand) training group, regarding the kinesthetic sense or AJPS of the symptomatic shoulders. Salles et $\mathrm{al}^{26}$ investigated the effects of a strength training program (Table 6) on elite volleyball players with and without an infraspinatus muscular atrophy. Their findings suggest that only the group with an identified infraspinatus atrophy demonstrated improvements in proprioceptive ability $(P<.001)$; however, their proprioceptive acuity was not better than the healthy nonatrophy group of volleyball players, even following the 8-week intervention $(P<.001)$. Pairot de Fontenay et $\mathrm{al}^{46}$ also evaluated the effects of a 6-week rehabilitation program (Table 6) on AJPS and kinesthesia among individuals with RC tendinopathy. Their findings support the evidence presented by Salles et al, ${ }^{26}$ suggesting that only the participants with an identified proprioceptive deficit preintervention demonstrated improvements postintervention $(P=.022)$. Both Salles et $\mathrm{al}^{26}$ and Pairot de Fontenay et $\mathrm{al}^{46}$ calculated the effect size for their interventions (Table 8). Both studies indicate a large effect size (range: 0.719-2.94) for their intervention group, for both shoulder joint position sense and kinesthesia, following conventional therapies. The healthy control groups in both studies did not support a large effect size (range: $0.022-0.16$ ), suggesting no real improvement in the sense of shoulder proprioception over time.

Finally, Jung and Choi ${ }^{42}$ evaluated the AJPS of individuals affected by a shoulder subluxation poststroke, following an active exercise program with a sling suspension system and sandbag weights (1-3 kg; intervention) or a bilateral upper-extremity training program (control). Their results support the use of a sling suspension system poststroke for a statistically significant improvement in shoulder proprioception, when compared with the control group $\left(3.83^{\circ}\left[1.72^{\circ}\right]\right.$ vs $\left.1.56^{\circ}\left[0.61^{\circ}\right], P=.006\right)$.

There is minimal decisive evidence that conventional therapies as used in the included studies directly improve the sense of shoulder proprioception. 
Table 6 Conservative Interventions Applied to the Shoulder Complex

\begin{tabular}{|c|c|c|c|}
\hline Study & Population & Conservative treatment & Cluster \\
\hline Atya $^{16}$ & $\begin{array}{l}n=40 \\
\text { I: } n=19 \\
\text { C: } n=21 \\
\text { SIS }\end{array}$ & $\begin{array}{l}\text { MENS } \\
\text { HARLY physio } 3000 \text { unit } \\
(30-40 \mathrm{~mA}, 10 \mathrm{~Hz}, 50 \mathrm{~ms}, 20 \mathrm{~min} / \mathrm{session}, 18 \text { session, } 3 \text { times/wk) }\end{array}$ & IV \\
\hline $\begin{array}{l}\text { Başkurt } \\
\text { et } \text { al }^{17}\end{array}$ & $\begin{array}{l}\mathrm{n}=40 \\
\mathrm{I} 1: \mathrm{n}=20 \\
\mathrm{I} 2: \mathrm{n}=20 \\
\text { Unilateral SIS }\end{array}$ & $\begin{array}{l}\text { I1: Stretching, flexibility, and strengthening exercises } \\
\text { I2: Stretching, flexibility, and strengthening exercises + scapular stabilization exercises } \\
3 \text { sets ( } \uparrow \text { rep to } 10 \text { times), } 3 \text { times/wk, } 6 \mathrm{wk} \\
\text { Flexibility Ex: Anterior/posterior/inferior capsule stretching, forward flexion } \\
\text { and ABD AROM, IR stretching with towel } \\
\text { Strengthening Ex: Subscapularis, infraspinatus, supraspinatus, and anterior and posterior } \\
\text { part of deltoid strengthening } \\
\text { Scapular stabilization Ex: Scapular PNF, scapular clock, standing weight shift, } \\
\text { double-arm balancing, scapular depression, wall push-up, and wall slides }\end{array}$ & I \\
\hline Chu et $\mathrm{al}^{45}$ & $\begin{array}{l}\mathrm{n}=40 \\
\mathrm{I}: \mathrm{n}=20 \\
\mathrm{C}: \mathrm{n}=20 \\
\text { Shoulder anterior } \mathrm{GH} \\
\text { dislocation }\end{array}$ & $\begin{array}{l}\text { Braced condition } \\
\text { A neoprene sully shoulder stabilizer brace }\end{array}$ & IV \\
\hline Dilek et al ${ }^{18}$ & $\begin{array}{l}n=61 \\
\mathrm{I}: \mathrm{n}=31 \\
\text { C: } \mathrm{n}=30 \\
\text { SIS }\end{array}$ & $\begin{array}{l}\text { NSAIDs permitted with both groups } \\
\text { Both groups: } 6 \text { wk, } 3 \mathrm{~d} / \mathrm{wk}, 1 \text { time/wk at home, after } 6 \mathrm{wk}: 2 \text { times/d at home } \\
\text { C: Conventional physiotherapy program } \\
\text { Transcutaneous electrical nerve stimulation + hot pack and Exs } \\
\text { Phase I: Maximum protection } \\
\text { - Active rest, ROM exercises (pendulum exercises, passive, and active assisted ROM } \\
\text { with a stick), posterior capsular stretches, and patient education for activity modification } \\
\text { Phase II: Strengthening and stability } \\
\text { - Strengthening Ex of the rotator cuff, scapular stabilizers, and deltoid muscles (isometric } \\
\text { exercises, TheraBands, and free weights) } \\
\text { - Scapular stabilizers: shoulder shrugs, press-ups, and push-ups } \\
\text { Phase III: Functional return } \\
\text { - Unrestricted symptom-free ADLs, occupation, recreational activities, and sports. } \\
\text { Activities progressively increased to prepare the patient for full functional return } \\
\text { I: Conventional physiotherapy and proprioceptive training } \\
\text { - } 10 \times 5 \text { for each Ex } \\
\text { - Static weight bearing on floor } \\
\text { - Balance with } 1 \text { hand, clockwise on the wall } \\
\text { - Double-arm balance, kneeling push-up position on balance board } \\
\text { - Rotation on the wall using a ball } \\
\text { - Scapular stabilization on floor with } 1 \text { hand } \\
\text { - Dynamic stabilization on ball with } 1 \text { hand } \\
\text { Ref: http://links.lww.com/PHM/A128 }\end{array}$ & $\begin{array}{l}\text { I } \\
\text { II } \\
\text { IV }\end{array}$ \\
\hline $\begin{array}{l}\text { Keenan } \\
\text { et al }{ }^{19}\end{array}$ & $\begin{array}{l}n=30 \\
\text { SIS (20) } \\
\text { Healthy }(10) \\
\text { I: } n=10 \\
\text { C: } n=10\end{array}$ & $\begin{array}{l}\text { KT } \\
\text { C: KT tape } \\
\text { I: KT tape or PT }\left(\text { Cover-Roll }{ }^{\circledR}\right) \\
\text { Application for all participants: Supraspinatus "Y" stip, "I" strip, and Deltoid "Y" strip }\end{array}$ & III \\
\hline Mörl et $\mathrm{al}^{41}$ & $\begin{array}{l}\mathrm{n}=22 \\
\mathrm{I} 1: \mathrm{n}=12 \\
\mathrm{I} 2: \mathrm{n}=10 \\
\text { Aspecific shoulder pain }\end{array}$ & $\begin{array}{l}\text { I1: Flexible foil training (varied parameters) } \\
\text { Ex 1: Hold ambidextrously, keeping hands above head and swing up/down in sagittal } \\
\text { plane } \\
\text { Ex 2: Idem but oscillate the flexible foil back and forth } \\
\text { Ex 3: Single-arm oscillation on the side of the head } \\
\text { Ex 4: Idem with added control with oscillation through arm elevation } \\
\text { I2: Flexible bands training (TheraBands; } 3 \text { sets, } 5-10 \text { rep) } \\
\text { Ex 1: Programming-without TheraBands, lift } 1 \text { arm with elbow flexed at } 90^{\circ} \\
\text { Ex 2: Bilateral ER at } 90^{\circ} \text { of ABD with TheraBand } \\
\text { Ex 3: Programming by flexible band-combination of Ex } 1 \text { and Ex } 2 \\
\text { Ex 4: Continuation of Ex } 3 \text { with trunk tilted through low flexion of the hips and knees } \\
\text { - } 12 \text { wk and } 2 \text { times/wk } \\
\text { - 20-min active therapy } \\
\text { - 30-min total workout }\end{array}$ & $\begin{array}{l}\text { I } \\
\text { II }\end{array}$ \\
\hline
\end{tabular}


Table 6 (continued)

\begin{tabular}{|c|c|c|c|}
\hline Study & Population & Conservative treatment & Cluster \\
\hline $\begin{array}{l}\text { Naughton } \\
\text { et } \mathrm{al}^{14}\end{array}$ & $\begin{array}{l}\mathrm{n}=30 \\
\mathrm{I}: \mathrm{n}=15 \text { (injured arm) } \\
\mathrm{C}: \mathrm{n}=15 \text { (uninjured arm) } \\
\text { Anterior dislocation }\end{array}$ & $\begin{array}{l}\text { Upper-body wobble board training (bilateral) } \\
\text { C: Check any learning effects on the discrimination test. No additional training during } \\
\text { the testing period. } \\
\text { I: Wobble board training with a Swiss ball (diameter } 75 \mathrm{~cm} \text { ) and a wobble board } \\
\text { (diameter } 42 \mathrm{~cm} \text { ). } 10 \mathrm{~min} \text { each day, } 5-6 \text { times } / \mathrm{wk}, 1 \mathrm{~m} \text {. Exercise was not progressed. }\end{array}$ & II \\
\hline Shih et $\mathrm{al}^{25}$ & $\begin{array}{l}\mathrm{n}=30 \\
\mathrm{I}: \mathrm{n}=15 \\
\mathrm{C}: \mathrm{n}=15 \\
\text { Overhead athletes SIS }\end{array}$ & $\begin{array}{l}\text { KT } \\
\text { C: PT. 3M Micropore tape without any stretch tension. } \\
\text { I: KT group, we taped both the UT (I tape) and LT (Y tape) using the KT. }\end{array}$ & III \\
\hline Salles et $\mathrm{al}^{26}$ & $\begin{array}{l}\mathrm{n}=54 \\
\mathrm{I}: \text { Atrophy } \mathrm{n}=18 \\
\text { nonatrophy } \mathrm{n}=18 \\
\text { C: Healthy nonathletic } \mathrm{n}=18\end{array}$ & $\begin{array}{l}\text { Strength training routine } \\
\text { I: IAG and NAG } \\
\text { •Normal strength training routine consisting of basic exercises for upper and lower limbs. } \\
\text { IAG (in addition to normal strengthening) dominant limb only: } \\
2 \text { sets of } 3 \text { Exs during } 8 \mathrm{wk}, 4 \text { times/wk ( } 32 \text { sessions) } \\
\text { Ex 1: Supraspinatous fly } \\
\text { Ex 2: Shoulder external rotation } \\
\text { Ex 3: Lying "L" fly } \\
\text { Intensity individually adjusted, loads with free weights increased to } 8-12 \text { repetitions } \\
\text { maximum. Started ECC, worked toward CON without help. } \\
\text { C: No intervention during experimental period }\end{array}$ & I \\
\hline $\begin{array}{l}\text { Pairot de } \\
\text { Fontenay } \\
\text { et } \mathrm{al}^{46}\end{array}$ & $\begin{array}{l}\mathrm{n}=20 \text { with } \mathrm{RC} \text { tendinopathy } \\
\text { for longitudinal study }\end{array}$ & $\begin{array}{l}\text { Rehabilitation program (10 supervised PT sessions over } 6 \mathrm{wk}) \\
\text { •Movement training } \\
\text { •Manual therapy } \\
\text { • Strengthening and stretching } \\
\text {-Patient education }\end{array}$ & I \\
\hline $\begin{array}{l}\text { Jung and } \\
\text { Choi }^{42}\end{array}$ & $\begin{array}{l}\mathrm{n}=36 \\
\text { All poststroke with } \\
\text { subluxation } \\
\mathrm{I}=18 \\
\mathrm{C}=18\end{array}$ & $\begin{array}{l}\text { I: Active shoulder exercises using sling suspension system } \text { (Redcord }^{\mathrm{TM}} \text { exercise therapy } \\
\text { device; Redcord AS, Staubo, Norway) sandbag } 1-3 \mathrm{~kg} \\
\text { Each Ex performed } 20 \text { times, } 5 \text { sets/session } \\
\text { •Horizontal ABD/add shoulder Exs in sitting } \\
\text { •IR/ER at } 90^{\circ} \text { ABD shoulder Exs in sitting } \\
\text { • Flex/ext shoulder Exs in sitting } \\
\text { •ABD/add shoulder Exs in supine } \\
\text { C: Bilateral arm training ( } 40 \text { min, } 5 \mathrm{~d} / \text { wk for } 4 \mathrm{wk} \text { ) sandback } 1-3 \mathrm{~kg} \\
\text {-Flex/ext shoulder Exs in sitting } \\
\text { •Flex/ext elbow Exs in sitting } \\
\text { •Forward reaching Exs in supine } \\
\text { •Pull into the body Ex (position not mentioned) }\end{array}$ & I \\
\hline $\begin{array}{l}\text { de Oliveira } \\
\text { et } \mathrm{al}^{12}\end{array}$ & $\begin{array}{l}\mathrm{n}=23 \\
\text { Chronic RC tendinopathy }\end{array}$ & $\begin{array}{l}\text { Kinesio Tex classic }{ }^{\circledR} \text { Tape (symptomatic shoulder only) } \\
\text { Taping technique: } \\
\text {-Specifically for RC tendinopathy } \\
\text { •Y strip: Deltoid insertion to origin ( } 15 \%-25 \% \text { tension) } \\
\text {-I strip: Below deltoid tuberosity to above the AC Joint }(50 \%-75 \% \text { tension) } \\
\text {-I strip: Coracoid process to post. deltoid with inward pressure }(50 \%-75 \% \text { tension) }\end{array}$ & III \\
\hline
\end{tabular}

Abbreviations: ABD, abduction; AC, acromioclavicular; add, adduction; ADLs, activities of daily living; ant, antiflexion; AROM, active range of motion; C, control group; CON, concentric contraction; ECC, eccentric contraction; ER, external rotation; Ex/Exs, exercises; Ext, extension; Flex, Flexion; GH, glenohumeral; I, intervention group; IAG, infraspinatus atrophy group; IR, internal rotation; KT, kinesiology tape; LT, lower trapezius muscle; MENS, microcurrent electrical stimulation; n, population; NAG, nonatrophy of infraspinatus group; NSAIDs, nonsteroid anti-inflammatory drug; PNF, proprioceptive neuromuscular facilitation; PT, placebo taping; RC, rotator cuff; rep, repetitions; SIS, subacromial impingement syndrome; UT, upper trapezius muscle. Note: Cluster intervention classification: I, conventional therapy; II, proprioceptive training; III, elastic kinesiology tape; and IV, other passive modalities.

Hence, strength of conclusion being Level 2.

Proprioceptive Training. Two studies evaluated the effects of proprioceptive training in combination with conventional therapy, ${ }^{17,18}$ whereas 2 studies ${ }^{14,41}$ solely evaluated the effects of proprioceptive training on shoulder proprioception. Başkurt et al ${ }^{17}$ found that the group that received the proprioceptive neuromuscular facilitation as part of their scapular stabilization exercises was significantly improved $(P<.05)$ for both joint position sense and scapular dyskinesia when compared with the group with stretching, flexibility, and strengthening exercises only. Dilek et $\mathrm{al}^{18}$ examined the change overtime between a conventional program (control) and a conventional program with proprioceptive training (intervention) among individuals with SIS. They reported that the control group had no significant difference in sense of proprioception (kinesthesia, AJPS, and PJPS) at $10^{\circ}$ of ER. However, they did find that the intervention group with proprioceptive training demonstrated significant gains in proprioception (kinesthesia, AJPS, and PJPS) at $10^{\circ}$ of ER. When both groups were compared for the other tested parameters (pain, ROM, strength, or function), there were no statistically significant differences $(P<.05)$. This hints at a possible specificity of training effect with shoulder proprioception.

Mörl et $\mathrm{a}^{41}$ reported no change in the ability of participants with unspecific shoulder pain to replicate shoulder angles actively after 12 weeks of flexible foil or flexible band training $(P>.05)$, except for 
Table 7 Synthesis of Results With Established Strength of Conclusion

\begin{tabular}{|c|c|c|}
\hline $\begin{array}{l}\text { Treatment } \\
\text { cluster }\end{array}$ & $\begin{array}{c}\text { Strength of } \\
\text { conclusion (1-4) }\end{array}$ & Take-home message \\
\hline $\begin{array}{l}\text { Conventional } \\
\text { therapy }\end{array}$ & 2 & $\begin{array}{l}\text { - JPS (active and passive) improved for both conventional therapy (stretching and strengthening) and the } \\
\text { conventional therapy and scapular stabilization group. The improvements in the scapular stabilization } \\
\text { group were found to be superior. Population: SIS. } \\
\text { - No difference between conventional therapy and proprioceptive training. Both groups improved with } \\
\text { kinesthesia, but the proprioceptive training group also improved with AJPS and PJPS. Population: SIS. } \\
\text { - No difference reported for kinesthesia or AJPS between flexible foil training and flexible band } \\
\text { (TheraBand) training. Population: Nonspecific shoulder pain. } \\
\text { - Only the group with infraspinatus atrophy improved in kinesthesia and JPS after strength training. } \\
\text { Population: Elite volleyball players with infraspinatus atrophy. } \\
\text { - Proprioception acuity improved after a rehabilitation program, only among those with an identified } \\
\text { deficit. Population: RC tendinopathy. } \\
\text { - Significant shoulder proprioception improvements following active exercises with a sling suspension } \\
\text { system. Population: Individuals poststroke with a shoulder subluxation. }\end{array}$ \\
\hline $\begin{array}{l}\text { Proprioceptive } \\
\text { training }\end{array}$ & 3 & $\begin{array}{l}\text { - PNF techniques and stabilization exercises improved JPS and scapular dyskinesia, compared with } \\
\text { conventional therapy. Population: SIS. } \\
\text { - No difference between conventional therapy or conventional therapy and proprioceptive training for } \\
\text { pain/ROM/strength/function; but an improvement was noted with the proprioceptive training group for } \\
\text { kinesthesia/AJPS/PJPS. Population: SIS. } \\
\text { - No real difference between flexible foil or flexible band (TheraBand) training for AJPS, except for } 120^{\circ} \\
\text { of ABD. Population: Nonspecific shoulder pain. }\end{array}$ \\
\hline Elastic KT & 3 & $\begin{array}{l}\text { - There is no significant improvement with kinesthesia or AJPS, between KT or placebo tape. Population: } \\
\text { SIS and RC tendinopathy. } \\
\text { - There was a greater improvement among the KT group for scapular reposition during scapular } \\
\text { protraction, when compared with the placebo tape group. Population: Overhead athletes with SIS. }\end{array}$ \\
\hline $\begin{array}{l}\text { Other passive } \\
\text { therapies }\end{array}$ & 2 & $\begin{array}{l}\text { - PJPS did not improve with the application of MENS; there were no significant differences between a } \\
\text { MENS and placebo MENS treatment. Population: SIS. } \\
\text { - AJPS in ABD/ER/IR did not improve with a neoprene brace. AJPS did improve near max ER. } \\
\text { Population: anterior shoulder instabilities. } \\
\text { - No difference reported between conventional therapy (TENS/hot packs/stretching/strengthening) vs } \\
\text { proprioceptive training for kinesthesia at } 0^{\circ} \text { of ABD. The proprioceptive training group did demonstrate } \\
\text { improvements for kinesthesia/AJPS/PJPS at } 10^{\circ} \text { of ER. Population: SIS. }\end{array}$ \\
\hline
\end{tabular}

Abbreviations: ABD, abduction; AJPS, active joint position sense; EBRO, evidence-based Richtlijn Ontwikkeling; ER, external rotation; IR, internal rotation; KT, kinesiology tape; PJPS, passive joint position sense; PNF, proprioceptive neuromuscular facilitation; SIS, shoulder impingement syndrome. Note: N.B. CBO/EBRO strength of conclusion. Level 2: 1 A2 (blinded RCTs) or at least 2 independent B (comparative) studies. Level 3: 1 B (comparative studies) or C (noncomparative) study or conflicting evidence.

Table 8 Reported Effect Sizes

\begin{tabular}{|c|c|c|c|}
\hline Study & Population & Effect size & Intervention cluster and SOC \\
\hline Salles et $\mathrm{al}^{26}$ & $\begin{array}{l}\mathrm{n}=54 \text { Elite volley ball players } \\
\mathrm{C}=18 \\
\mathrm{IAG}=18 \\
\mathrm{NAG}=18\end{array}$ & $\begin{array}{l}\text { Cohen formula } \\
\text { TTDPM: } \\
\text { C: }-0.044 \\
\text { IAG: }-0.719 \\
\text { NAG: }-0.316 \\
\text { AJPS: } \\
\text { C: }-0.022 \\
\text { IAG: }-2.94 \\
\text { NAG: }-0.117\end{array}$ & $\begin{array}{l}\text { Intervention: } 8 \text {-wk strengthening program } \\
\text { Cluster: I } \\
\text { Conventional therapy } \\
\text { SOC: } 2\end{array}$ \\
\hline Pairot de Fontenay et al ${ }^{46}$ & $\begin{array}{l}n=40(\text { Exp II }) \\
\text { C: } n=20 \text { (healthy) } \\
\text { I: } n=20 \text { (rotator cuff tendinopathy) }\end{array}$ & $\begin{array}{l}\text { Glasse } \Delta \\
\text { AJPS: } \\
\text { C: } 0.16 \\
\text { I: }-0.97\end{array}$ & $\begin{array}{l}\text { Intervention: } 6 \text {-wk rehabilitation program } \\
\text { Cluster: I } \\
\text { Conventional therapy } \\
\text { SOC: } 2\end{array}$ \\
\hline
\end{tabular}

Abbreviations: AJPS, active joint position sense; C, control; I, intervention; IAG, infraspinatus atrophy group; n, population; NAG, nonatrophy group; SOC, strength of conclusion; TTDPM, threshold to detect passive movement (kinesthesia). 
the flexible band group in abduction at $120^{\circ}(P<.05) .^{41}$ Contrastingly, Naughton et al, ${ }^{14}$ who studied a population with a history of anterior shoulder dislocations, indicated that the discrimination of active shoulder movements (kinesthesia) in a position near dislocation improved significantly after upper-body wobble board training $(P<.001)$ for both shoulders; however, significantly greater improvements were seen for the injured compared with the noninjured side $(P<.01)$.

Moderate evidence suggests that proprioceptive training, more specifically upper-body wobble board training, and flexible foil training, can improve proprioceptive acuity in individuals with a known proprioceptive disability. Furthermore, 2 studies reported improvements in the sense of shoulder proprioception postconventional therapies only among the groups that had a measurable proprioceptive deficit at the baseline, ${ }^{26,46}$ perhaps suggesting that only populations with known proprioceptive deficits can improve their proprioceptive acuity. This may also put forward the possibility of a floor (basement) effect with the current methods of measuring shoulder proprioception.

Hence, strength of conclusion being level 3 .

Kinesiology Tape. Three studies examined the effects of elastic KT. Keenan et $\mathrm{al}^{19}$ reported that, after both the elastic KT and the placebo nonelastic tape application, threshold to detection of passive movement (kinesthesia) did not significantly improve for shoulder internal rotation and ER $(P>.05)$ and that elastic KT was not significantly superior to the placebo nonelastic tape for either internal rotation or ER $(P>.05)$. de Oliveira et al ${ }^{12}$ also report no statistically significant changes $(P=.0140-.497)$ in AJPS in flexion or abduction following the application of Tex Classic $\mathrm{KT}^{\circledR}$ to the shoulders affected by a RC tendinopathy. In opposition, Shih et $\mathrm{al}^{25}$ demonstrated that elastic KT of the shoulder improved the 3-dimensional scapular reposition errors (AJPS) in a scapular protraction task significantly more than the placebo tape $(P<.05)$. It is worth noting that all 3 studies applied different types of elastic KT, followed different taping application protocols (Table 6), and applied the tape to different populations, notably, SIS, ${ }^{19}$ overhead athletes with SIS, ${ }^{25}$ and participants with RC tendinopathy. ${ }^{12}$

Presently, there exists conflicting evidence for the improvement of proprioceptive acuity with the application of elastic KT.

Hence, the strength of conclusion being level 3 .

Other Passive Therapies. Finally, 3 studies ${ }^{16,18,45}$ questioned the efficacy of passive therapies. Atya ${ }^{16}$ revealed that PJPS did not improve significantly after a 6-week program of MENS $(P=.067)$, with no significant differences between the placebo and the true MENS intervention $(P=.84)$. Chu et al ${ }^{45}$ demonstrated that the AJPS in $90^{\circ}$ abduction and $30^{\circ}$ internal rotation/ ER did not improve significantly while wearing the neoprene brace $(P>.05)$. However, AJPS did improved significantly close to the maximal ER $(P<.05)$. Dilek et $a^{18}$ used TENS and hot packs as part of their conventional therapy program. Their conventional therapy group did equally as well as the proprioceptive training group for their kinesthetic sense at $0^{\circ}$ of abduction; however, the proprioceptive training group demonstrated significant improvements for kinesthesia, AJPS, and PJPS at $10^{\circ}$ of ER $(P<.05)$. There were no other statistically significant differences between the 2 groups.

There is moderate evidence to suggest that passive therapies, such as TENS, MENS, and bracing, are not effective for enhancing shoulder proprioception.

Hence, the strength of conclusion being level 2 .

\section{Discussion}

This systematic review summarized the current evidence regarding the effects of rehabilitation interventions on shoulder proprioception in populations with shoulder disorders. A previous review of 8 articles by Armitt et al $^{55}$ investigated whether a conservative (bracing and wobble board training) or surgical intervention improved shoulder proprioception; however, their results were only applicable to a population affected by anterior shoulder instability. Their review suggested improvements in AJPS over time with both surgical and conservative approaches; nonetheless, they recommended more rigorous comparative studies to support their findings. By contrast, this review included various shoulder pathologies and explored the effects of active and passive modalities.

\section{Pain, Function, and Proprioception}

Notwithstanding the shoulder proprioception outcome measures of interest, the included studies also evaluated other outcomes concurrently, including shoulder pain, ${ }^{16-18,41}$ functional disability, ${ }^{16-18,42,46}$ ROM,${ }^{17,18,45}$ strength, ${ }^{14,17-19,26}$ muscle activation, ${ }^{25}$ lateral scapular tilting, ${ }^{17}$ subacromial distance, ${ }^{12}$ and scapular kinematics. ${ }^{19,25,41}$ Still, no clear correlational relationship between the aforementioned outcomes were established within the studies. In fact, the association between shoulder pain, functional ability, and proprioception remains conflicted and contradictory between researchers. Atya ${ }^{16}$ reported a decrease in pain with a MENS treatment, but no significant change to shoulder proprioception. Similarly, Mörl et $\mathrm{al}^{41}$ evaluated the relation between pain and proprioception $(r=-.02, P>.05)$ and stated that pain intensity is not associated with a good or poor capability in proprioception. Moreover, Dilek et al ${ }^{18}$ asserted that proprioception exercises did indeed improve proprioception acuity, but offered no additional positive effects to any other clinical parameters (pain, ROM, strength, and Western Ontario Rotator Cuff [WORC] index score). There is growing evidence to support a lack of a crossover rehabilitation effect between pain management, shoulder function, and proprioception acuity. Hence, there is a potential indication that shoulder proprioception acuity can only be improved specifically through targeted proprioceptive training ${ }^{14,18}$ when a proprioceptive deficit has been quantifiably established. ${ }^{14,26,46}$

\section{Proprioceptive Training}

The specific proprioceptive gains seen with shoulder proprioceptive training can be partially justified by the targeted activation of localized mechanoreceptors, such as muscle spindles. ${ }^{14,17,18}$ Proprioceptive exercises encourage a tensile loading mechanism, such as with the weight-bearing wobble board training and the reactive rehabilitation of the flexible foil training, which would stimulate the articular (ruffini endings and pacinian corpuscles) ${ }^{56}$ and muscular receptors (Meissner's corpuscle, pacinian corpuscle, ruffini endings, muscle spindles such as Ia and IIa afferent receptors $)^{57,58}$ directly. Furthermore, there may be an indirect increase to the mechanoreceptor inputs of the surrounding soft tissues, such as within the joint capsule, ligaments, and cutaneous tissues. ${ }^{41}$ This could partially explain why passive therapies such as MENS, TENS, and bracing are not effective ${ }^{16,18,45}$ at generating a change in proprioceptive acuity, as arguably, no active stimulation of the mechanoreceptors occurred. 


\section{Kinesiology Tape}

The conflicting evidence $12,19,25$ can be partially justified by the differences in the applied taping protocols, which at present, there is no standardized proprioceptive taping protocol for the shoulder complex. Nonetheless, the reported positive effects of KT seen with the scapular reposition task among participants with SIS $^{25}$ could be rationalized through the suggested enhancement of sensory feedback within the peripheral mechanoreceptors found within the skin, the muscles, or both, thus, inducing muscle-length changes.$^{51}$ It has been suggested that tape can cause improvements in the position sense and the kinematics of the scapula, which may provide a better proximal stability to the glenohumeral joint. ${ }^{25}$ There is no clear evidence that KT directly affects the sense of proprioception of the shoulder, but rather, supports a possible improvement in biomechanical alignment during movement. Further investigation into the biomechanical effects of elastic KT to the shoulder complex during movement is warranted to support this hypothesis.

\section{Specificity of Proprioceptive Deficits}

Our review included several shoulder pathologies, arguably, with distinct shoulder proprioceptive deficits. The noted improvements in proprioception within the included studies are congruent with the suspected deficits of the population of study. For example, the overhead athletic population with SIS demonstrated targeted AJPS improvements with a scapular elastic KT, potentially improving their overhead biomechanics and movement patterns. ${ }^{25}$ The anterior instability population demonstrated AJPS improvements with a neoprene brace only at end range ER. ${ }^{45}$ Similarly, Naughton et $\mathrm{al}^{14}$ observed an increased sense of kinesthesia to both shoulders with upper-body wobble board training, although the injured shoulder demonstrated greater improvements when compared with the contralateral healthy shoulder.

Pairot et Fontenay et $\mathrm{al}^{46}$ analyzed the effects of their intervention by creating subcategories of their population based on the identified proprioceptive deficits at the baseline. Individuals with an RC tendinopathy were either categorized as having a "deficit" or having "normal" proprioceptive acuity at the baseline. It was through this approach that they were able to assert an improvement in proprioceptive acuity over time, only among those with an identified baseline deficit. Likewise, 2 other studies with an SIS population only noted improvements in kinesthesia, AJPS, and PJPS with purposeful proprioceptive training, when compared with conventional therapy. ${ }^{17,18}$ The aggregate of these findings suggests that specific proprioceptive deficit patterns are worth exploring for particular shoulder pathologies. This, in turn, will guide clinicians to specific proprioception exercises in-line with the distinct proprioceptive deficits associated with the shoulder pathology.

\section{Strengths and Limitations}

A prevalent strength of this systematic review includes the independent, blinded, and thorough screening process and methodological quality assessment of the studies. A limitation includes the various timelines for the proprioception outcome measures, ranging from the immediate effects, ${ }^{14,16-18}$ as well as after an applied external intervention ${ }^{14,16-19,25,45}$ including up to 12 weeks postintervention. ${ }^{41}$ Thus, the application of our results is limited to a midterm effect (up to $12 \mathrm{wk}$ ). This presented a challenge for the synthesis of results, as well as the application of our results to a clinical setting. In addition, patient populations and proprioceptive outcome measures were not homogenous, preventing the pooling of data into a meta-analysis. Furthermore, small sample sizes $^{14,19,41,45}$ resulted in weaker statistical power and conflicting results. Only 2 studies ${ }^{26,46}$ examined the effect size of their interventions, limiting the establishment of the magnitude of change over time. Future research should include RCT studies (level A2) with larger sample sizes and established effect sizes for proprioception interventions, to ensure more confident statistical inferences and clinical application.

\section{Take-Home Messages for Clinicians}

1. There is moderate evidence (level 3) for a specificity of training effect for the improvement of shoulder proprioception. Proprioceptive training may specifically improve the sense of shoulder proprioception. Further research is needed to support this inference.

2. Conventional therapy alone (ROM, stretching, strengthening, manual therapy, movement training, exercise prescription, and patient education) does not directly improve shoulder proprioception (level 3).

3. Conflicting evidence exists for the use of elastic KT for the improvement of shoulder proprioception.

4. Passive modalities, such as hot packs, TENS, MENS, or bracing, do not appear to improve shoulder proprioception (level 2), with the exception of a neoprene brace with end range movements in ER, for anterior instabilities.

\section{Conclusions}

The study of shoulder proprioception and the effects of conservative rehabilitative interventions are within its infancy. It is presently unclear how specific nonsurgical rehabilitative approaches influence the sense of proprioception of the shoulder. Specific proprioceptive training does support up to midterm improvements in shoulder proprioception. The effects of elastic KT on shoulder proprioception remain unclear at this time. There is moderate evidence to suggest that passive modalities do not improve shoulder proprioception. There is possibility of a specificity of training effect with shoulder proprioception where specific pathologies may benefit from specific proprioception interventions, in-line with their own pattern of proprioceptive deficits. Further research is encouraged to identify proprioception deficit patterns for specific shoulder pathologies.

\section{Acknowledgments}

This project did not receive funding from any sources. No conflict of interest exists from any of the authors involved in this paper.

\section{References}

1. Ager AL, Borms D, Deschepper L, et al. Proprioception: how is it affected by shoulder pain? A systematic review [published online ahead of print August 31, 2019]. J Hand Ther. 2019;S08941130(19):30094-8 doi:10.1016/j.jht.2019.06.002

2. Lephart SM, Fu FH, Lvf SU. The role of proprioception in the treatment of sports injuries. 1995. Retrieved from http://www.pitt. edu/ neurolab/publications/1992-1996/Articles/LephartSM_1995_ SportsExerInj_The\%20role\%20of\%20proprioception\%20in\%20the \% 20treatment $\% 20$ of $\% 20$ sports $\% 20$ injuries.pdf 
3. Ager AL, Roy JS, Roos M, Belley AF, Cools A, Hebert LJ. Shoulder proprioception: how is it measured and is it reliable? A systematic review. J Hand Ther. 2017;30(2):221-231. PubMed ID: 28641738 doi:10.1016/j.jht.2017.05.003

4. Lephart SM, Jari R. The role of proprioception in shoulder instability. Oper Tech Sports Med. 2002;10(1):2-4. doi:10.1053/otsm.2002. 29169

5. Lephart SM, Fu FH. Proprioception and Neuromuscular Control in Joint Stability. Champaign, IL: Human Kinetics; 2000.

6. Franklin DW, Wolpert DM. Computational mechanisms of sensorimotor control. Neuron. 2011;72(3):425-442. PubMed ID: 22078503 doi:10.1016/j.neuron.2011.10.006

7. Erickson RI, Karduna AR. Three-dimensional repositioning tasks show differences in joint position sense between active and passive shoulder motion. J Orthop Res. 2012;30(5):787-792. PubMed ID: 22072560 doi:10.1002/jor.22007

8. Koester MC, George MS, Kuhn JE. Shoulder impingement syndrome. Am J Med. 2005;118(5):452-455. PubMed ID: 15866244 doi:10.1016/j.amjmed.2005.01.040

9. Bigliani LU, Levine WN. Subacromial impingement syndrome. $J$ Bone Joint Surg Am. 1997;79(12):1854-1868. PubMed ID: 9409800 doi:10.2106/00004623-199712000-00012

10. Lephart SM, Warner JJ, Borsa PA, Fu FH. Proprioception of the shoulder joint in healthy, unstable, and surgically repaired shoulders. J Shoulder Elbow Surg. 1994;3(6):371-380. PubMed ID: 22958841 doi:10.1016/S1058-2746(09)80022-0

11. Maenhout AG, Palmans T, De Muynck MD, De Wilde LF, Cools AM. The impact of rotator cuff tendinopathy on proprioception, measuring force sensation. J Shoulder Elbow Surg. 2012;21(8): 1080-1086. PubMed ID: 22036534 doi:10.1016/j.jse.2011.07. 006

12. de Oliveira LFC, Pairot de Fontenay B, Bouyer LJ, Roy JS. Immediate effects of kinesiotaping on acromiohumeral head distance and shoulder proprioception in individuals with symptomatic rotator cuff tendinopathy. Clin Biomech. 2019;61:16-21. doi:10.1016/j. clinbiomech.2018.11.005

13. Smith RL, Brunolli J. Shoulder kinesthesia after anterior glenohumeral joint dislocation. Phys Ther. 1989;69(2):106-112. PubMed ID: 2913578 doi:10.1093/ptj/69.2.106

14. Naughton J, Adams R, Maher C. Upper-body wobbleboard training effects on the post-dislocation shoulder. Phys Ther Sport. 2005;6(1): 31-37. doi:10.1016/j.ptsp.2004.05.005

15. Jerosch J, Wustner P. The effect of a sensorimotor exercise program in patients with subacromial pain syndrome. Unfallchirurg. 2002;105(1):36-43. PubMed ID: 11968557 doi:10.1007/s113-0028163-3

16. Atya M. Efficacy of microcurrent electrical stimulation on pain, proprioception accuracy and functional disability in subacromial impingement: RCT. Indian J Physiother Occup Ther. 2012;6(1): $15-18$.

17. Başkurt Z, Başkurt F, Gelecek N, Özkan MH. The effectiveness of scapular stabilization exercise in the patients with subacromial impingement syndrome. J Back Musculoskelet Rehabil. 2011;24(3): 173-179. doi:10.3233/BMR-2011-0291

18. Dilek B, Gulbahar S, Gundogdu M, et al. Efficacy of proprioceptive exercises in patients with subacromial impingement syndrome: a single-blinded randomized controlled study. Am J Phys Med Rehabil. 2016;95(3):169-182. PubMed ID: 26098920 doi:10.1097/ PHM.0000000000000327

19. Keenan KA, Akins JS, Varnell M, et al. Kinesiology taping does not alter shoulder strength, shoulder proprioception, or scapular kinematics in healthy, physically active subjects and subjects with subacromial impingement syndrome. Phys Ther Sport. 2017;24:60-66. PubMed ID: 27665392 doi:10.1016/j.ptsp.2016. 06.006

20. Anderson VB, Wee E. Impaired joint proprioception at higher shoulder elevations in chronic rotator cuff pathology. Arch Phys Med Rehabil. 2011;92(7):1146-1151. PubMed ID: 21704796 doi:10. 1016/j.apmr.2011.02.004

21. Fabis J, Rzepka R, Fabis A, et al. Shoulder proprioception-lessons we learned from idiopathic frozen shoulder. BMC Musculoskelet Disord. 2016;17(1):123. PubMed ID: 26968796 doi:10.1186/ s12891-016-0971-5

22. Myers JB, Lephart SM. The role of the sensorimotor system in the athletic shoulder. J Athl Train. 2000;35(3):351-363. PubMed ID: 16558648

23. Allegrucci M, Whitney SL, Lephart SM, Irrgang JJ, Fu FH. Shoulder kinesthesia in healthy unilateral athletes participating in upper extremity sports. J Orthop Sports Phys Ther. 1995;21(4):220-226. PubMed ID: 7773274 doi:10.2519/jospt.1995.21.4.220

24. Wilk KE, Meister K, Andrews JR. Current concepts in the rehabilitation of the overhead throwing athlete. Am J Sports Med. 2002;30(1):136-151. PubMed ID: 11799012 doi:10.1177/ 03635465020300011201

25. Shih YF, Lee YF, Chen WY. Effects of kinesiology taping on scapular reposition accuracy, kinematics, and muscle activity in athletes with shoulder impingement syndrome: a randomized controlled study. J Sport Rehabil. 2018;27(6):560-569. PubMed ID: 29364027 doi:10.1123/jsr.2017-0043

26. Salles JI, Guimarães JM, Filho GM, Morrissey D. Efffect of a specific exercise strategy on strength and proprioception in volleyball players with infraspinatus muscle atrophy. Scand J Med Sci Sports. 2018;28(9):2093-2099. PubMed ID: 29772095 doi:10.1111/sms. 13216

27. Sahin E, Dilek B, Baydar M, et al. Shoulder proprioception in patients with subacromial impingement syndrome. J Back Musculoskelet Rehabil. 2017;30(4):857-862. PubMed ID: 28372317 doi:10.3233/ BMR-160550

28. Lubiatowski P, Ogrodowicz P, Wojtaszek M, Romanowski L. Bilateral shoulder proprioception deficit in unilateral anterior shoulder instability. J Shoulder Elbow Surg. 2019;28(3):561-569. PubMed ID: 30502033 doi:10.1016/j.jse.2018.08.034

29. Ingber RS. Shoulder impingement in tennis/racquetball players treated with subscapularis myofascial treatments. Arch Phys Med Rehabil. 2000;81(5):679-682. PubMed ID: 10807110 doi:10.1016/ S0003-9993(00)90053-4

30. Abrisham SMJ, Kermani-Alghoraishi M, Ghahramani R, et al. Additive effects of low-level laser therapy with exercise on subacromial syndrome: a randomised, double-blind, controlled trial. Clin Rheumatol. 2011;30(10):1341-1346.

31. Page MJ, Green S, Mrocki MA, et al. Electrotherapy modalities for rotator cuff disease. Cochrane Database Syst Rev. 2016;10(6): CD012225.

32. Senbursa G, Baltaci G, Atay A. Comparison of conservative treatment with and without manual physical therapy for patients with shoulder impingement syndrome: a prospective, randomized clinical trial. Knee Surg Sports Traumatol Arthrosc. 2007;15(7):915-921. PubMed ID: 17333123 doi:10.1007/s00167-007-0288-x

33. Bang MD, Deyle GD. Comparison of supervised exercise with and without manual physical therapy for patients with shoulder impingement syndrome. J Orthop Sports Phys Ther. 2000;30(3): 126-137. PubMed ID: 10721508 doi:10.2519/jospt.2000.30.3.126

34. Conroy DE, Hayes KW. The effect of joint mobilization as a component of comprehensive treatment for primary shoulder 
impingement syndrome. J Orthop Sports Phys Ther. 1998;28(1): 3-14. PubMed ID: 9653685 doi:10.2519/jospt.1998.28.1.3

35. Abdulla SY, Southerst D, Côté $P$, et al. Is exercise effective for the management of subacromial impingement syndrome and other soft tissue injuries of the shoulder? A systematic review by the Ontario Protocol for Traffic Injury Management (OPTIMa) Collaboration. Man Ther. 2015;20(5):646-656. PubMed ID: 25920340 doi:10.1016/ j.math.2015.03.013

36. Desmeules F, Boudreault J, Dionne CE, et al. Efficacy of exercise therapy in workers with rotator cuff tendinopathy: a systematic review. J Occup Health. 2016;58(5):389-403. doi:10.1539/joh.150103-RA

37. Dong W, Goost H, Lin XB, et al. Treatments for shoulder impingement syndrome: a PRISMA systematic review and network meta-analysis. Medicine. 2015;94(10):e510. doi:10.1097/MD. 0000000000000510

38. Holmgren T, Hallgren HB, Oberg B, Adolfsson L, Johansson K. Effect of specific exercise strategy on need for surgery in patients with subacromial impingement syndrome: randomised controlled study. Br J Sports Med. 2014;48(19):1456-1457. doi:10.1136/bjsports2014-e787rep

39. Struyf F, Nijs J, Mollekens S, et al. Scapular-focused treatment in patients with shoulder impingement syndrome: a randomized clinical trial. Clin Rheumatol. 2013;32(1):73-85. PubMed ID: 23053685 doi:10.1007/s10067-012-2093-2

40. Ager AL, Roy JS, Gamache F, Hébert LJ. The effectiveness of an upper extremity neuromuscular training program on the shoulder function of military members with a rotator cuff tendinopathy: a pilot randomized controlled trial. Mil Med. 2019;184(5-6):e385-e393. doi:10.1093/milmed/usy294

41. Mörl F, Matkey A, Bretschneider S, Bernsdorf A, Bradl I. Pain relief due to physiotherapy doesn't change the motor function of the shoulder. J Bodyw Mov Ther. 2011;15(3):309-318. doi:10.1016/j. jbmt.2010.06.008

42. Jung JM, Choi JD. The effects of active shoulder exercise with a sling suspension system on shoulder subluxation, proprioception, and upper extremity function in patients with acute stroke. Med Sci Monit. 2019;25:4849-4855. doi:10.12659/MSM.915277

43. Higgins JPT, Green S. Cochrane Handbook for Systematic Reviews of Interventions the Cochrane Collaboration. Version 5.0.1. 2008. www.cochrane-handbook.org. Updated September 2008.

44. Offringa M, Assendelft WJJ, Scholten RJPM. Inleiding in EvidenceBased Medicine. Amsterdam, NL: Bohn Stafleu van Loghum, Houten; 2014.

45. Chu JC, Kane EJ, Arnold BL, Gansneder BM. The effect of a neoprene shoulder stabilizer on active joint-reposition sense in subjects with stable and unstable shoulders. J Athl Train. 2002; 37(2):141-145. PubMed ID: 12937426
46. Pairot de Fontenay B, Mercier C, Bouyer L, Savoie A, Roy JS. Upper limb active joint repositioning during a multijoint task in participants with and without rotator cuff tendinopathy and effect of a rehabilitation program [published online ahead of print March 8, 2019]. J Hand Ther. S0894-1130(17)30285-5. doi:10.1016/j.jht.2018.09.009

47. Wells GA, Shea B, O'Connell D, et al. The Newcastle-Ottawa Scale (NOS) for Assessing the Quality of Nonrandomised Studies in Meta-Analyses. http://www.ohri.ca/programs/clinical_epidemiology/ oxford.asp. November 24, 2019.

48. van Everdingen JJE, Burgers JS, Assendelft W, Swinkels JA, van Barneveld TA, van de Klundert JLM. Evidence Based Richtlijnontwikkeling: Een Leidraad Voor de Praktijk. Utrecht, The Netherlands: Bohn Stafleu van Loghum; 2003. doi:10.1007/978-90-313-9397-8

49. (EBRO) E-bRO. Evidence-Based Guideline Development Manual for Working Group members Original Publication. 2005. http://www. ha-ring.nl/download/literatuur/EBRO_handl_totaal.pdf

50. Burgers JS, van Everdingen JJ. Evidence-based guideline development in the Netherlands: the EBRO platform. Ned Tijdschr Geneeskd. 2004;148(42):2057-2059. [Article in Dutch]. PubMed ID: 15532326

51. Lin JJ, Hung CJ, Yang PL. The effects of scapular taping on electromyographic muscle activity and proprioception feedback in healthy shoulders. J Orthop Res. 2011;29(1):53-57. PubMed ID: 20607815 doi:10.1002/jor.21146

52. Zanca GG, Mattiello SM, Karduna AR. Kinesio taping of the deltoid does not reduce fatigue induced deficits in shoulder joint position sense. Clin Biomech. 2015;30(9):903-907. doi:10.1016/j. clinbiomech.2015.07.011

53. dos Santos GL, Souza MB, Desloovere K, Russo TL. Elastic tape improved shoulder joint position sense in chronic hemiparetic subjects: a randomized sham-controlled crossover study. PLoS One. 2017;12(1):e0170368. doi:10.1371/journal.pone.0170368

54. Aman JE, Elangovan N, Yeh IL, Konczak J. The effectiveness of proprioceptive training for improving motor function: a systematic review. Front Hum Neurosci. 2015;8:1075. doi:10.3389/fnhum. 2014.01075

55. Armitt G, Pizzari T, Semciw A. The efficacy of interventions for improving shoulder proprioception in people with shoulder instability-a systematic review. J Sci Med Sports. 2017;20:e45. doi:10.1016/j.jsams.2017.01.125

56. Tuthill JC, Azim E. Proprioception. Curr Biol Mag. 2018;28:R187R207. Retrieved from http://faculty.washington.edu/tuthill/docs/ proprioprimer.pdf

57. French AST, Torkkeli PH. Reference module in neuroscience and biobehavioral psychology. In LR Squire. Encyclopedia of Neuroscience (pp. 689-695). San Diego, CA: Academic Press; 2009.

58. Proske U. Kinesthesia: the role of muscle receptors. Muscle Nerve. 2006;34(5):545-558. PubMed ID: 16897766 doi:10.1002/mus.20627 


\section{Appendix: Table of Evidence}

\begin{tabular}{|c|c|c|c|c|c|}
\hline $\begin{array}{l}\text { Reference } \\
\text { and study } \\
\text { design }\end{array}$ & $\begin{array}{l}\text { Sample and } \\
\text { population }\end{array}$ & $\begin{array}{l}\text { Experimental (I) } \\
\text { and Control (C) } \\
\text { groups }\end{array}$ & $\begin{array}{l}\text { Baseline } \\
\text { measurement }\end{array}$ & $\begin{array}{l}\text { Follow- } \\
\text { up + outcome } \\
\text { measurement }\end{array}$ & Results \\
\hline $\begin{array}{l}\text { Atya }^{16} \\
\text { RCT }\end{array}$ & $\begin{array}{l}n=40 \\
\text { I: } n=19 \\
\text { C: } n=21 \\
\text { SIS }\end{array}$ & $\begin{array}{l}\text { I: MENS } \\
\text { C: Placebo MENS } \\
\text { (electrodes not con- } \\
\text { nected to device, } \\
20 \mathrm{~min} / \mathrm{session}, 18 \\
\text { session, } 3 \text { times/wk) }\end{array}$ & $\begin{array}{l}0 \text { wk: } \\
\text { PJPS: } \\
\text { • Start: } \\
60^{\circ} \mathrm{ABD}, 0^{\circ} \mathrm{IR} / \mathrm{ER} \\
60^{\circ} \mathrm{ABD}, 30^{\circ} \mathrm{ER} \\
\text { • Reference angle: } \\
10^{\circ} \mathrm{IR}, 10^{\circ} \mathrm{ER}, 20^{\circ} \mathrm{ER} \text {, } \\
40^{\circ} \mathrm{ER} \\
\text { (isokinetic } \\
\text { dynamometer) }\end{array}$ & $\begin{array}{l}6 \text { wk: after MENS } \\
\text { PJPS: } \\
\text { - Start: } \\
60^{\circ} \mathrm{ABD}, 0^{\circ} \mathrm{IR} / \mathrm{ER} \\
60^{\circ} \mathrm{ABD}, 30^{\circ} \mathrm{ER} \\
\text { - Reference } \\
\text { angle: } \\
10^{\circ} \mathrm{IR}, 10^{\circ} \mathrm{ER}, \\
20^{\circ} \mathrm{ER}, 40^{\circ} \mathrm{ER}\end{array}$ & $\begin{array}{l}\text { No significant difference between groups } \\
\text { for proprioception accuracy } \\
(P=.067) \\
\text { Mean proprioceptive accuracy PJPS: } \\
\text { Pretest-posttest I: } P=.067 \\
\text { Pretest-posttest C: } P=.231 \\
\text { Pretest I-C: } P=.255 \\
\text { Posttest I-C: } P=.84\end{array}$ \\
\hline $\begin{array}{l}\text { Başkurt } \\
\text { et al }{ }^{17} \\
\text { Randomized } \\
\text { trial }\end{array}$ & $\begin{array}{l}\mathrm{n}=40 \\
\mathrm{I} 1: \mathrm{n}=20 \\
\text { I2: } \mathrm{n}=20 \\
\text { Unilateral SIS }\end{array}$ & $\begin{array}{l}\text { I: Stretching, } \\
\text { strengthening, and } \\
\text { scapular stabilization } \\
\text { Exs } \\
\text { C: Stretching and } \\
\text { strengthening }\end{array}$ & $\begin{array}{l}0 \text { wk: } \\
\text { PJPS: } \\
\text { IR } \\
\text { ER } \\
90^{\circ} \mathrm{ABD} \\
\text { shoulder }+90^{\circ} \text { flexion } \\
\text { elbow, supine } 3 \text { times } \\
\text { (inclinometer) }\end{array}$ & $\begin{array}{l}6 \text { wk (after } \\
\text { program): } \\
\text { PJPS: } \\
\text { IR } \\
\text { ER }\end{array}$ & $\begin{array}{l}\text { PJPS: statistically improved in both groups } \\
(P<.05) \\
\text { I1: } \\
\text { ER } \uparrow(P<.05) \\
\text { IR } \uparrow(P<.05) \\
\text { I2: } \\
\text { ER } \uparrow(P<.05) \\
\text { IR } \uparrow(P<.05) \\
\text { JPS } \uparrow \text { I } 2>\text { I1 } \\
\text { ER }(P=.00) \\
\text { IR }(P=.00)\end{array}$ \\
\hline $\begin{array}{l}\text { Chu et } \mathrm{al}^{45} \\
\text { Crossover } \\
\text { study }\end{array}$ & $\begin{array}{l}n=20 \\
\mathrm{I}: \mathrm{n}=20 \\
\text { C: } \mathrm{n}=20 \\
\text { Shoulder } \\
\text { anterior GH } \\
\text { dislocation }\end{array}$ & $\begin{array}{l}\text { I: Braced condition } \\
\text { C: Nonbraced } \\
\text { condition }\end{array}$ & $\begin{array}{l}\text { AJPS: } \\
\text { Supine, } 90^{\circ} \mathrm{ABD}, 90^{\circ} \\
\text { flexion elbow, } 0^{\circ} \mathrm{IR} / \\
\mathrm{ER} \text { ) } \\
10^{\circ} \text { from full ER } \\
30^{\circ} \mathrm{ER} \\
30^{\circ} \mathrm{IR} \\
\text { (isokinetic } \\
\text { dynamometer) }\end{array}$ & $\begin{array}{l}\text { AJPS: } \\
\text { Affected shoulder, } \\
\text { supine, } 90^{\circ} \mathrm{ABD}, \\
\left.0^{\circ} \mathrm{IR} / \mathrm{ER}\right) \\
10^{\circ} \text { from full ER } \\
30^{\circ} \mathrm{ER} \\
30^{\circ} \mathrm{IR}\end{array}$ & $\begin{array}{l}\text { Braced condition improved JPS at max } \\
\text { ER. } \\
\text { AJPS: } \\
10^{\circ} \text { from full ER } \uparrow(P<.05) \\
30^{\circ} \text { ER }(P>.05) \\
30^{\circ} \mathrm{IR}(P>.05) \\
\text { Mean degree of error AJPS } 10^{\circ} \text { from full } \\
\text { ER }>\text { mean degree of error } 30^{\circ} \\
\text { IR } / 30^{\circ} \text { ER }(P<.05)\end{array}$ \\
\hline $\begin{array}{l}\text { Dilek et al }^{18} \\
\text { Single-blind } \\
\text { RCT }\end{array}$ & $\begin{array}{l}n=61 \\
\text { I: } n=31 \\
\text { C: } n=30 \\
\text { SIS }\end{array}$ & $\begin{array}{l}\text { I: Conventional PT } \\
\text { program and proprio- } \\
\text { ceptive Exs } \\
\text { C: Conventional PT } \\
\text { program: } \\
\text { TENS } \\
\text { Hot pack } \\
\text { Conventional exercise } \\
\text { program ( } 6 \mathrm{wk}, 3 \mathrm{~d} / \\
\text { wk, } 1 \text { time/wk at } \\
\text { home, after } 6 \mathrm{wk}: \\
2 \text { times/d at home) }\end{array}$ & $\begin{array}{l}0 \text { wk: } \\
\text { Kinesthesia } \\
\text { AJPS } \\
\text { PJPS } \\
\text { (isokinetic dynamome- } \\
\text { ter, } 90^{\circ} \mathrm{ABD}, 0^{\circ} / 10^{\circ} \\
\text { ER) }\end{array}$ & $\begin{array}{l}6 \mathrm{wk} \text { (immediately } \\
\text { after intervention) } \\
\text { Kinesthesia } \\
\text { AJPS } \\
\text { PJPS } \\
12 \mathrm{wk} \text { (6 wk after } \\
\text { intervention) } \\
\text { Kinesthesia } \\
\text { AJPS } \\
\text { PJPS }\end{array}$ & 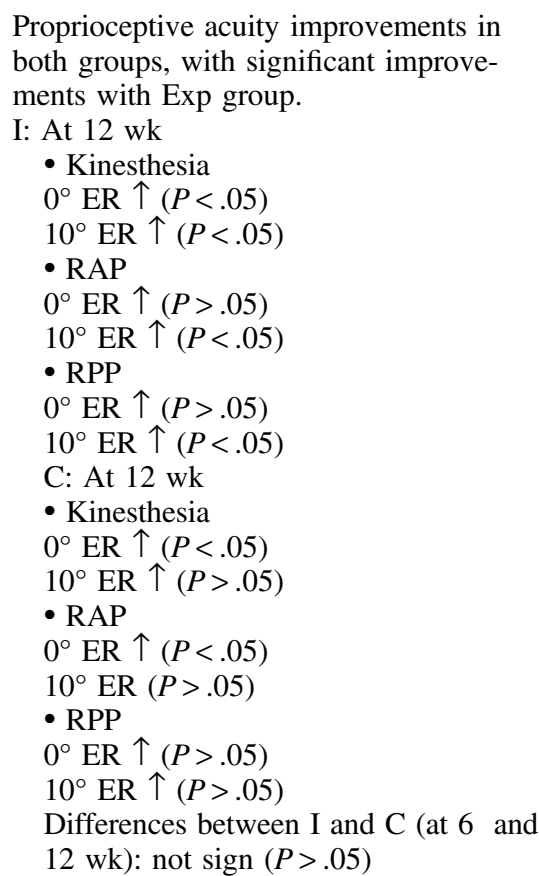 \\
\hline
\end{tabular}


(continued)

\begin{tabular}{|c|c|c|c|c|c|}
\hline $\begin{array}{l}\text { Reference } \\
\text { and study } \\
\text { design }\end{array}$ & $\begin{array}{l}\text { Sample and } \\
\text { population }\end{array}$ & $\begin{array}{l}\text { Experimental (I) } \\
\text { and Control (C) } \\
\text { groups }\end{array}$ & $\begin{array}{l}\text { Baseline } \\
\text { measurement }\end{array}$ & $\begin{array}{l}\text { Follow- } \\
\text { up + outcome } \\
\text { measurement }\end{array}$ & Results \\
\hline $\begin{array}{l}\text { Keenan } \\
\text { et al }^{19} \\
\text { Single-blind } \\
\text { placebo-con- } \\
\text { trolled trial }\end{array}$ & $\begin{array}{l}\mathrm{n}=30 \text { (total) } \\
10 \text { healthy and } \\
20 \text { SIS } \\
\text { I: } n=10 \\
\text { C: } n=10\end{array}$ & $\begin{array}{l}\text { I: KT } \\
\text { C: PT with Cover- } \\
\text { Roll }^{\circledR}\end{array}$ & $\begin{array}{l}\text { Before tape application: } \\
\text { Kinesthesia TTDPM: } \\
3 \text { times ER } \\
3 \text { times IR } \\
\text { (isokinetic } \\
\text { dynamometer) }\end{array}$ & $\begin{array}{l}\text { After tape applica- } \\
\text { tion: } \\
\text { Kinesthesia } \\
\text { TTDPM: } \\
3 \text { times ER } \\
3 \text { times IR }\end{array}$ & $\begin{array}{l}\text { No significant within group or between } \\
\text { group differences were demonstrated for } \\
\text { any measure. } \\
\text { KT TTDPM: } \\
\text { ER pretest-posttest }(P=.444) \\
\text { IR pretest-posttest }(P=.333) \\
\text { PT TTDPM: } \\
\text { ER pretest-posttest }(P=.333) \\
\text { IR pretest-posttest }(P=.721) \\
\text { KT vs PT TTDPM: } \\
\text { ER posttest }(P=.280) \\
\text { IR posttest }(P=.739)\end{array}$ \\
\hline $\begin{array}{l}\text { Mörl et } \mathrm{al}^{41} \\
\text { Randomized } \\
\text { trial }\end{array}$ & $\begin{array}{l}\mathrm{n}=22 \\
\mathrm{I} 1: \mathrm{n}=12 \\
\mathrm{I} 2: \mathrm{n}=10 \\
\text { Aspecific } \\
\text { shoulder pain }\end{array}$ & $\begin{array}{l}\text { Gr I: Flexible foil } \\
\text { Gr II: Flexible band }\end{array}$ & $\begin{array}{l}0 \text { wk } \\
\text { Active-active angle- } \\
\text { replication test (AJPS): } \\
\text { ANT } 60^{\circ}, 90^{\circ}, 120^{\circ} \\
\text { ABD } 60^{\circ}, 90^{\circ}, 120^{\circ} \\
\text { IR } \\
\text { ER } \\
\text { (Zebris CMS-HS } \\
\text { 3-dimensional motion } \\
\text { measuring system, } \\
\text { Zebris Medical GmbH, } \\
\text { Allgäu Germany) }\end{array}$ & $\begin{array}{l}12 \text { wk (after training } \\
\text { period) } \\
\text { Active-active } \\
\text { angle-replication } \\
\text { test (AJPS): } \\
\text { ANT } 60^{\circ}, 90^{\circ}, 120^{\circ} \\
\text { ABD } 60^{\circ}, 90^{\circ}, 120^{\circ} \\
\text { IR } \\
\text { ER }\end{array}$ & $\begin{array}{l}\text { No change in proprioceptive ability in } \\
\text { either group. } \\
\text { Flexible foil: } \\
\text { AJPS ANT } 60^{\circ}, 90^{\circ}, 120^{\circ}, \text { ABD } 60^{\circ}, 90^{\circ}, \\
120^{\circ}(P>.05) \\
\text { Flexible band: } \\
\text { AJRS } \uparrow \text { ABD } 120^{\circ}(P<.05) \\
\text { AJRS ANT } 60^{\circ}, 90^{\circ}, 120^{\circ}, \text { ABD } 60^{\circ}, 90^{\circ} \\
(P>.05)\end{array}$ \\
\hline $\begin{array}{l}\text { Naughton } \\
\text { et al }{ }^{14} \\
\text { Case control }\end{array}$ & $\begin{array}{l}\mathrm{n}=30 \\
\text { Anterior dis- } \\
\text { locations } \\
\mathrm{I}: \mathrm{n}=15 \\
\text { (injured arm) } \\
\mathrm{C}: \mathrm{n}=15 \\
\text { (uninjured } \\
\text { arm) } \\
60 \text { shoulders }\end{array}$ & $\begin{array}{l}\text { I: Swiss ball and } \\
\text { wobble board training } \\
\text { C: No training }\end{array}$ & $\begin{array}{l}0 \text { wk: } \\
\text { Kinesthesia: } \\
\text { - Active discrimina- } \\
\text { tion between posi- } \\
\text { tions } \\
90^{\circ} \mathrm{ABD}+\mathrm{ER} \\
\text { Positions 1-5 } \\
\text { Uninjured + injured } \\
\text { arm } \\
\text { (TTDPM overhead } \\
\text { position testing appara- } \\
\text { tus with a computer } \\
\text { interface) }\end{array}$ & $\begin{array}{l}1 \mathrm{~m} \text { (after training } \\
\text { period): } \\
\text { Kinesthesia: } \\
\text { - Active discrim- } \\
\text { ination between po- } \\
\text { sitions } \\
90^{\circ} \mathrm{ABD}+\mathrm{ER} \\
\text { Positions 1-5 } \\
\text { Uninjured + injured } \\
\text { arm }\end{array}$ & $\begin{array}{l}\text { Significant proprioception improvement } \\
\text { for dislocated shoulders compared with } \\
\text { controls, and a greater improvement for the } \\
\text { involved compared with the uninvolved } \\
\text { shoulder. } \\
\text { Discrimination } \uparrow(P<.001) \\
\text { Injured arm }>\text { uninjured arm }(P<.01) \\
\text { Injured arm }(P<.001) \\
\text { Uninjured arm }(P<.001)\end{array}$ \\
\hline $\begin{array}{l}\text { Shih et } \mathrm{al}^{25} \\
\mathrm{RCT} \text {-single } \\
\text { blind }\end{array}$ & $\begin{array}{l}\mathrm{n}=30 \\
\quad \mathrm{I}: \mathrm{n}=15 \\
\mathrm{C}: \mathrm{n}=15 \\
\text { Overhead ath- } \\
\text { letes SIS }\end{array}$ & $\begin{array}{l}\text { I: KT } \\
\text { C: PT }\end{array}$ & $\begin{array}{l}\text { Before tape application: } \\
\text { Scapular AJPS: } \\
\text { Scapular elevation } \\
\text { task } \\
\text { Scapular AT/PT } \\
\text { Scapular ER/IR } \\
\text { Scapular UR/DR } \\
\text { Displacement } \\
(x-, y-, z \text {-axes }) \\
\text { Scapular protraction } \\
\text { Scapular tilt } \\
\text { Scapular ER/IR } \\
\text { Scapular UR/DR } \\
\text { Displacement } \\
\text { (x-, } y \text {-, } z \text {-axes) } \\
\text { (3-dimensional Liberty } \\
\text { electromagnetic track- } \\
\text { ing system, Polhemus, } \\
\text { Colchester,VE) }\end{array}$ & $\begin{array}{l}\text { After tape applica- } \\
\text { tion: } \\
\text { Scapular AJPS: } \\
\text { Scapular eleva- } \\
\text { tion task } \\
\text { Scapular } \\
\text { protraction }\end{array}$ & $\begin{array}{l}\text { Significant }(P=.040) \text { improvements in } \\
\text { scapular repositioning task with KT. } \\
\text { Scapular AJPS: } \\
\text { Protraction task } \\
\text { KT vs CT } \\
\text { AT/PT } \uparrow \mathrm{KT}>\mathrm{CT}(P=.04) \\
\mathrm{UR} / \mathrm{DR} \uparrow \mathrm{KT}>\mathrm{CT}(P=.04) \\
y \text {-axis displacement } \uparrow \mathrm{KT}>\mathrm{KT} \\
(P=.046)\end{array}$ \\
\hline
\end{tabular}




\begin{tabular}{|c|c|c|c|c|c|}
\hline $\begin{array}{l}\text { Reference } \\
\text { and study } \\
\text { design }\end{array}$ & $\begin{array}{l}\text { Sample and } \\
\text { population }\end{array}$ & $\begin{array}{l}\text { Experimental (I) } \\
\text { and Control (C) } \\
\text { groups }\end{array}$ & $\begin{array}{l}\text { Baseline } \\
\text { measurement }\end{array}$ & $\begin{array}{l}\text { Follow- } \\
\text { up + outcome } \\
\text { measurement }\end{array}$ & Results \\
\hline $\begin{array}{l}\text { Salles et al } \\
\text { Case control }\end{array}$ & $\begin{array}{l}\mathrm{n}=54 \\
\text { Elite volley- } \\
\text { ball players } \\
\text { I: (IAG) atro- } \\
\text { phy } \mathrm{n}=18 \\
\text { (NAG) nona- } \\
\text { trophy } \mathrm{n}=18 \\
\mathrm{C}: \text { Healthy } \\
\text { nonathletic } \\
\mathrm{n}=18 \\
\text { Dominant } \\
\text { limb }\end{array}$ & $\begin{array}{l}\text { I: Strength training } \\
\text { program } \\
\text { C: No intervention }\end{array}$ & $\begin{array}{l}0 \text { wk: preintervention } \\
\text { AJPS: } \\
\text { Starting position } \\
\text { (max ER at } 90^{\circ} \\
\text { ABD) as } 0^{\circ} \text {, end } \\
\text { position } 45^{\circ} \text { IR } \\
\text { (isokinetic dyna- } \\
\text { mometer) } \\
\text { Kinesthesia TTDPM: } \\
\text { (custom-made } \\
\text { motor-driven device) } \\
\text { IR at } 90^{\circ} \mathrm{ABD}\end{array}$ & $\begin{array}{l}8 \text { wk: postinterven- } \\
\text { tion } \\
\text { AJPS: } \\
\text { Starting position } \\
\text { (max ER at } 90^{\circ} \\
\text { ABD) as } 0^{\circ} \text {, end } \\
\text { position } 45^{\circ} \text { IR } \\
\text { Kinesthesia } \\
\text { TTDPM: } \\
\text { (custom-made } \\
\text { motor-driven } \\
\text { device) } \\
\text { IR at } 90^{\circ} \mathrm{ABD}\end{array}$ & $\begin{array}{l}\text { Only IAG improved both proprioceptive } \\
\text { acuities after training }(P<.001) \text {, but still } \\
\text { worse than NAG }(P<.001) \text {. } \\
\text { JPS: } \\
\text { IAG: } \uparrow 1.36(P<.001) \\
\text { NAG: } \uparrow 0.05(P<.001) \\
\text { CG: no change }(P<.001) \\
\text { Kinesthesia TTDPM: } \\
\text { IAG: } \uparrow 0.9(P<.001) \\
\text { NAG: } \uparrow 0.3(P<.001) \\
\text { CG: No change }(P<.001)\end{array}$ \\
\hline $\begin{array}{l}\text { Pairot de } \\
\text { Fontenay } \\
\text { et al }{ }^{46} \\
\text { Cross-sec- } \\
\text { tional and } \\
\text { longitudinal } \\
\text { (exploratory) }\end{array}$ & $\begin{array}{l}\mathrm{n}=60 \\
\mathrm{I}: \mathrm{n}=20 \mathrm{RC} \\
\text { tendinopathy } \\
\mathrm{I}: \text { Another } \\
\mathrm{n}=20 \text { with } \\
\mathrm{RC} \text { tendino- } \\
\text { pathy for lon- } \\
\text { gitudinal } \\
\text { study } \\
\mathrm{C}: \mathrm{n}=20 \\
\text { healthy } \\
\text { participants }\end{array}$ & $\begin{array}{l}\text { I: Rehabilitation pro- } \\
\text { gram } \\
\text { Movement training } \\
\text { Manual therapy } \\
\text { Strengthening and } \\
\text { stretching } \\
\text { Patient education } \\
\text { Participants acted as } \\
\text { their own control dur- } \\
\text { ing the longitudinal } \\
\text { study }\end{array}$ & $\begin{array}{l}0 \text { wk: Preintervention } \\
\text { AJPS: } \\
\text { Passive-active protocol } \\
\text { ER: } 30^{\circ} \text { and } 45^{\circ} \\
\text { NR: sagittal plane } \\
\text { IR: } 30^{\circ} \text { and } 45^{\circ} \\
\text { Multijoint-reposition- } \\
\text { ing task (custom built) }\end{array}$ & $\begin{array}{l}6 \text { wk: Postinterven- } \\
\text { tion } \\
\text { AJPS: } \\
\text { Passive-active pro- } \\
\text { tocol } \\
\text { ER: } 30^{\circ} \text { and } 45^{\circ} \\
\text { NR: sagittal plane } \\
\text { IR: } 30^{\circ} \text { and } 45^{\circ}\end{array}$ & $\begin{array}{l}\text { Proprioception acuity improved after } \\
\text { rehabilitation among those with an iden- } \\
\text { tified deficit (global mean error above } \\
32.40^{\circ} \text { ). } \\
2 \text { subgroups were created, based on pro- } \\
\text { prioceptive ability before } \\
\text { rehabilitation program: } \\
\text { DEF }=\mathrm{n}=10 \text { Improvement in } \\
\text { proprioception acuity }(P=.022) \\
\text { NORM }=\mathrm{n}=13 \text { No difference in } \\
\text { proprioception acuity }(P=.69)\end{array}$ \\
\hline $\begin{array}{l}\text { Jung and } \\
\text { Choi }^{42} \\
\text { Single-blind } \\
\text { RCT }\end{array}$ & $\begin{array}{l}\mathrm{n}=36 \\
\mathrm{I}: \mathrm{n}=18 \text { post- } \\
\text { stroke with } \\
\text { shoulder sub- } \\
\text { luxation } \\
\mathrm{C}: \mathrm{n}=18 \\
\text { poststroke } \\
\text { with shoulder } \\
\text { subluxation }\end{array}$ & $\begin{array}{l}\text { I: Active exercises } \\
\text { with sling suspension } \\
\text { system } \\
\text { C: Bilateral arm } \\
\text { training }\end{array}$ & $\begin{array}{l}0 \text { wk: Preintervention } \\
\text { AJPS: } \\
\text { Passive-active reposi- } \\
\text { tion task } \\
\text { Flexion: } 30^{\circ}, 60^{\circ}, 90^{\circ} \text {, } \\
120^{\circ}, 150^{\circ} \\
\text { Paralyzed arm in a } \\
\text { sling, side-lying } \\
\text { position(sling } \\
\text { apparatus) }\end{array}$ & $\begin{array}{l}4 \text { wk: Postinterven- } \\
\text { tion } \\
\text { AJPS: } \\
\text { Passive-active } \\
\text { reposition task } \\
\text { Flexion: } 30^{\circ}, 60^{\circ} \text {, } \\
90^{\circ}, 120^{\circ}, 150^{\circ} \\
\text { Paralyzed arm in a } \\
\text { sling, side-lying } \\
\text { position }\end{array}$ & $\begin{array}{l}\text { Shoulder proprioception significantly } \\
\text { improved in (I) compared with }(\mathrm{C}) \text { group } \\
\left(3.83^{\circ}\left[1.72^{\circ}\right] \text { vs } 1.56^{\circ}\left[0.61^{\circ}\right], P=.006\right) \text {. }\end{array}$ \\
\hline $\begin{array}{l}\text { de Oliveira } \\
\text { et al }{ }^{12} \\
\text { Cross- } \\
\text { sectional } \\
\text { study }\end{array}$ & $\begin{array}{l}\mathrm{n}=23 \\
1 \text { participant } \\
\text { excluded } \\
\mathrm{n}=22 \\
\text { Chronic } \mathrm{RC} \\
\text { tendinopathy }\end{array}$ & $\begin{array}{l}\text { I: Kinesio Tex classic } \\
\text { for RC tendinopathy } \\
\text { C: No taping }\end{array}$ & $\begin{array}{l}\text { Pretaping } \\
\text { AJPS: Active-active } \\
\text { protocol } \\
\text { Flexion and ABD } \\
\text { (4 positions total) } \\
\text { Low: } 40^{\circ}-45^{\circ} \\
\text { Mid: } 80^{\circ}-100^{\circ} \\
\text { (IMU sensors and laser } \\
\text { pointer) }\end{array}$ & $\begin{array}{l}\text { Posttaping } \\
\text { AJPS: Active- } \\
\text { active protocol } \\
\text { Flexion and ABD } \\
\text { (4 positions total) } \\
\text { Low: } 40^{\circ}-45^{\circ} \\
\text { Mid: } 80^{\circ}-100^{\circ}\end{array}$ & $\begin{array}{l}\text { No statistically significant differences were } \\
\text { found in proprioceptive ability } \\
\text { pre or post tape for any tested angles } \\
(P=.140-.497) \text {. }\end{array}$ \\
\hline
\end{tabular}

Abbreviations: $\uparrow$, an improvement in proprioceptive ability; ABD, abduction; AJPS, active joint position sense; ANT, antireflexion; C, control; CG, control group; DR, downward rotation; DEF, deficit group; ER, external rotation; Ex/Exs, exercises; GH, glenohumeral; I, intervention; IAG, infraspinatus atrophy group; IMU, inertial measurement unit; IR, internal rotation; JPS, joint position sense; KT, kinesiology tape; MENS, microcurrent electrical stimulation; NAG, nonatrophy of infraspinatus group; NR, neutral rotation; NORM, normal group; PJPS, passive joint position sense; PT, placebo tape; RAP, reproduction of active repositioning; RC, rotator cuff; RCT, randomized control trail; RPP, reproduction of passive repositioning; SIS, subacromial impingement syndrome; TENS, transcutaneous electrical nerve stimulation; TTDPM, threshold to detect passive movement (kinesthesia); UR, upward rotation. 